Conceição | Conception

Revista do Programa de Pós-Graduação em Artes da

Cena, Universidade Estadual de Campinas

Performing Arts Graduate Program Journal, University of

Campinas

\title{
Dança e Empoderamento
}

\section{Dance and Empowerment}

Mariana Baruco Machado Andraus ${ }^{1}$

Lívia Sene ${ }^{2}$

Isadora Prata ${ }^{3}$

Clara Rodriguez ${ }^{4}$

Milena Pereira 5

\section{Resumo}

Este artigo se dedica a refletir sobre o papel do licenciado em dança no empoderamento de cidadãos por meio do trabalho corporal sensível e crítico propiciado pelo estudo da dança.

Palavras-chave: Ensino de dança. Empoderamento. Concepções de corpo. Teorias de conhecimento.

\begin{abstract}
This article focuses on the role of the dance bachelor in the empowerment of citizens through the sensitive and critical corporal work provided by the study of dance.

Keywords: Dance teaching. Empowerment. Body conceptions. Knowledge theories.
\end{abstract}

\footnotetext{
${ }^{1}$ Universidade Estadual de Campinas. Professora do Programa de Pós-Graduação em Artes da Cena e dos Cursos de Bacharelado e Licenciatura em Dança. ORCID: https://orcid.org/0000-0003-44608555 Contato: mandraus@g.unicamp.br

2 Bacharel e Licenciada em Dança pela Universidade Estadual de Campinas. ORCID: https:/ / orcid.org/0000-0002-1445-4607 Contato: liviamtsene@gmail.com

3 Bacharel e Licenciada em Dança pela Universidade Estadual de Campinas. ORCID: https://orcid.org/0000-0002-1445-2644 Contato: isadora.pgp@gmail.com

4 Bacharel e Licenciada em Dança pela Universidade Estadual de Campinas. ORCID: https://orcid.org/0000-0001-9999-1470 Contato: clara.tomie.heider@gmail.com

5 Bacharel e Licenciada em Dança pela Universidade Estadual de Campinas. ORCID: https://orcid.org/0000-0002-4008-6633 E-mail: miiilenapereira@gmail.com
} 
Conceição | Conception

Revista do Programa de Pós-Graduação em Artes da

Cena, Universidade Estadual de Campinas

Performing Arts Graduate Program Journal, University of

Campinas

\begin{abstract}
"Nosso corpo nos pertence!"- gritavam no começo dos anos 1970 as mulheres que protestavam contra as leis que proibiam o aborto, pouco tempo antes que os movimentos homossexuais retomassem o mesmo slogan. $\mathrm{O}$ discurso e as estruturas estavam estreitamente ligados ao poder, ao passo que o corpo estava do lado das categorias oprimidas e marginalizadas: as minorias de raça, de classe ou de gênero pensavam ter apenas o próprio corpo para opor ao discurso do poder, à linguagem como instrumento para impor o silêncio aos corpos (JEAN-JACQUES COURTINE, 2009).
\end{abstract}

Cursos superiores de formação em dança existem no Brasil desde a década de 1950, com projetos pedagógicos que contemplam disciplinas de Anatomia, Fisiologia, Cinesiologia - apresentando semelhanças, nesse sentido especificamente, com uma formação em Educação Física, porém com disciplinas especializadas de práticas de técnicas diversificadas de dança desde o primeiro até o oitavo e último semestre do curso, inteirando quatro anos, nas quais se abordam, entre outros conteúdos, a consciência corporal para a execução de movimentos cunhados para engendrar uma estética condizente com o tempo e contexto em que o profissional da dança atua.

A dança possui suas leis próprias - além da Lei 13.278/2016, que dispõe sobre a obrigatoriedade da dança no ensino formal, existe a Lei 644/2015, que regulamenta especificamente o exercício profissional da dança:

Art. $2^{\circ}$ Compete ao Profissional da Dança exercer as atividades de coreógrafo, auxiliar de coreógrafo, bailarino, dançarino ou intérpretecriador, diretor de dança, diretor de ensaio, diretor de movimento, dramaturgo de dança, ensaiador de dança, professor de curso livre de dança, maitre de ballet ou professor de ballet, crítico de dança, curador, diretor de espetáculos de dança, bem como planejar, coordenar e supervisionar trabalhos, planos e projetos e prestar serviços de consultoria na área da dança (SENADO FEDERAL WEBSITE, 2016b).

A dança obteve avanços, nas últimas décadas, quanto às políticas que a regulamentam como profissão, e paralelamente a isso se estabeleceu como área de 
Conceição | Conception

Revista do Programa de Pós-Graduação em Artes da

Cena, Universidade Estadual de Campinas

Performing Arts Graduate Program Journal, University of

Campinas

conhecimento acadêmico com episteme e métodos próprios, reconhecidos e legitimados por pares, tal como a estrutura social científica identificada por Kuhn em sua análise das ciências, apresentada em The Structure of Scientific Revolutions (KUHN, 2013). Coloca-se, neste momento, a necessidade de ampliar a publicidade deste conhecimento, que, justamente por ser conhecimento, não deveria estar circunscrito a uma classe profissional específica, mas ser um legado da humanidade para a humanidade. Enquanto a ideia de pertencimento vigorar apenas no âmbito de discussões epistêmicas - que, por sua vez, refletem nas políticas -, os maiores prejudicados são as cidadãs e cidadãos brasileiros.

Para elaborar este artigo partimos da percepção de uma histórica cisão entre corpo e mente, vivida pela sociedade ocidental ao longo dos séculos XVI ao XX que, ao retirar da mente a prerrogativa de ser corpo, e do corpo a possibilidade de ser sujeito, culmina em certo estado experienciado hoje por tantas pessoas que outorgam ao outro (o médico, o professor...) a autoridade sobre si. Diz Moulin:

\begin{abstract}
A história do corpo no século $X X$ é a de uma medicalização sem equivalente. Ao assumir e enquadrar um sem-número de atos ordinários da vida, indo além daquilo que fora anteriormente imaginável, a assim chamada medicina ocidental tornou-se não apenas o principal recurso em caso de doença, mas um guia de vida concorrente das tradicionais direções de consciência (MOULIN, 2009, p. 15).
\end{abstract}

Neste capítulo do livro História do Corpo (CORBIN, COURTINE, VIGARELLO, 2009) sugere-se que a medicalização se apresenta como um modo de vida no qual o foco é a doença, e não a saúde. Para a autora, a medicina ocidental

promulga regras de comportamento, censura os prazeres, aprisiona o cotidiano em uma rede de recomendações. Sua justificação reside no progresso de seus conhecimentos sobre o funcionamento do organismo e a vitória sem precedentes que reivindica sobre as enfermidades, atestada pelo aumento regular da longevidade (MOULIN, 2009, p. 15). 
Conceição | Conception

Revista do Programa de Pós-Graduação em Artes da

Cena, Universidade Estadual de Campinas

Performing Arts Graduate Program Journal, University of

Campinas

Ou seja, vivemos ainda um reflexo das correntes positivistas que caracterizaram de forma predominante a medicina do século XIX refletida em uma prática médica que desapropria o corpo do sujeito. Nos tempos atuais, urge reafirmar o empoderamento como caminho necessário para uma "reapropriação" de si:

A história do corpo no século XX é a de uma expropriação que talvez chegue um dia a fazer de cada um o médico de si mesmo, tomando a iniciativa e as decisões com pleno conhecimento de causa. Sonho encorajado pela ideia de uma transparência do corpo, um corpo totalmente exposto, explorado em suas profundezas e, afinal, diretamente acessível ao próprio sujeito (MOULIN, 2009, p. 16).

A passagem acima - escrita por autora francesa - não se permite entender sem que antes esteja pressuposto um amplo esclarecimento da população, esclarecimento que só se atinge mediante uma educação para o livre pensamento. Coerções e aprisionamentos conceituais, como quer um programa como o Programa Escola Sem Partido, por exemplo, levam para um lugar que não o da liberdade intelectual, no qual o aluno formaria sua própria opinião à medida que coloca sua liberdade em diálogo com opiniões diversas. E o diverso inclui não apenas ideais "modelares" de homem ou de mulher, mas todas as possibilidades de construção de gênero comportadas pela sociedade.

Dessa forma, estruturamos este artigo com quatro tópicos principais: "Individualidade e diversidade no ensino de dança: um caminho para o empoderamento do indivíduo", "Um ensino de dança empoderador: enfrentando os desafios da formação híbrida contemporânea em dança", "Corpo perfeito, eixo deslocado" e "Que relação tem a dança com empoderamento?", desenvolvidos de forma independente e relacionados à temática comum “Dança e Empoderamento". 
Conceição | Conception

Revista do Programa de Pós-Graduação em Artes da

Cena, Universidade Estadual de Campinas

Performing Arts Graduate Program Journal, University of

Campinas

\section{Individualidade e diversidade no ensino de dança: um caminho para o empoderamento do indivíduo}

No atual contexto político e social do Brasil é possível observar uma polarização de posicionamentos e o fervilhar de radicalismos que veem na oposição um inimigo a ser combatido e silenciado. Diante de tal situação, têm surgido diversas propostas para reformas na educação que levantam a bandeira da neutralidade política e ideológica das instituições de ensino e da ação de cada educador. Entre essas propostas se destaca o Programa Escola Sem Partido, que defende a ideia de que o ambiente educacional deve ser imparcial e, portanto, não deveria abordar questões que possam tendenciar a visão dos alunos, não ir contra os valores de cada estudante e dos seus responsáveis, e não prejudicá-lo em caso de oposição à visão do docente. Apresento aqui trecho do texto explicativo encontrado no site do programa em 10 de outubro de 2016:

A doutrinação política e ideológica em sala de aula ofende a liberdade de consciência do estudante; afronta o princípio da neutralidade política e ideológica do Estado; e ameaça o próprio regime democrático, na medida em que instrumentaliza o sistema de ensino com o objetivo de desequilibrar o jogo político em favor de um dos competidores. Por outro lado, a exposição, em disciplina obrigatória, de conteúdos que possam estar em conflito com as convicções morais dos estudantes ou de seus pais, viola o art. 12 da Convenção Americana sobre Direitos Humanos, segundo o qual "os pais têm direito a que seus filhos recebam a educação religiosa e moral que esteja de acordo com suas próprias convicções. Essas práticas, todavia, apesar de sua manifesta inconstitucionalidade e ilegalidade, tomaram conta do sistema de ensino. A pretexto de "construir uma sociedade mais justa" ou de "combater o preconceito", professores de todos os níveis vêm utilizando o tempo precioso de suas aulas para "fazer a cabeça" dos alunos sobre questões de natureza político-partidária, ideológica e moral. Que fazer para coibir esse abuso intolerável da liberdade de ensinar, que se desenvolve no segredo das salas de aula, e tem como vítimas indivíduos vulneráveis em processo de formação? Nada mais simples: basta informar e educar os alunos sobre o direito que eles têm de não ser doutrinados por seus professores; basta informar e 
Conceição | Conception

Revista do Programa de Pós-Graduação em Artes da

Cena, Universidade Estadual de Campinas

Performing Arts Graduate Program Journal, University of

Campinas

educar os professores sobre os limites éticos e jurídicos da sua liberdade de ensinar (WEBSITE DO PROGRAMA ESCOLA SEM PARTIDO, 2016).

A passagem supracitada suscita, de antemão, duas questões a serem problematizadas: a primeira delas é o fato de ser baseada em uma convenção norteamericana de 1969, muito anterior à Constituição Brasileira de 1988 (WEBSITE DA CÂMARA DOS DEPUTADOS, 2018), reconhecida e elogiada internacionalmente como referência no que concerne a Direitos Humanos. A segunda é a falácia em que se baseia o argumento, à medida em que o texto faz parecer que o Estado tenta impor uma ideologia, quando, na verdade, o estado atual das legislações de ensino assegura, pelo contrário, a diversidade de ideologias.

Cabe aqui, ainda, questionar o conceito de neutralidade ideológica e política apresentado no texto acima, já que a palavra ideologia traz a noção de um ideal que guia princípios e ações. Sendo, ainda, uma ideologia relacionada a um fenômeno social - tal qual o ato educacional - é, também, política. Assim, qualquer proposta que diga respeito à educação é, inevitavelmente, ideológica e política, fazendo-se impossível qualquer tipo de neutralidade em relação à mesma, pois sempre haverá um ideal regendo e direcionando as ações a serem feitas e os posicionamentos com ela promovidos. Além disso, apenas o entendimento de que a educação se faz diretamente e unicamente por meio de indivíduos, seres subjetivos, já coloca em cheque a ideia de neutralidade e imparcialidade promovida por um programa político como o Programa Escola Sem Partido.

Desta maneira - considerando que tudo aquilo que é feito em um contexto social é inevitavelmente ideológico - o que seria então o neutro e imparcial apresentados acima senão uma hierarquização de pontos de vista, colocando um deles como o fundamental e todos os demais como alterações ou distorções do mesmo? Logo, promove-se a ideia de que há um único ponto de vista essencial, "correto" e mais importante a ser abordado no ambiente educacional, fortalecendo assim não apenas uma visão de mundo, mas também o grupo social de onde se 
Conceição | Conception

Revista do Programa de Pós-Graduação em Artes da

Cena, Universidade Estadual de Campinas

Performing Arts Graduate Program Journal, University of

Campinas

origina essa visão. Assim, esse conceito amplia a voz de um único grupo e busca calar todas as outras vozes, já que estas, quando se levantam, estão apenas "questionando uma verdade inquestionável".

Essa sobreposição e hierarquização de discursos acontece não apenas no ambiente educacional. Historicamente pode-se observar o pensamento do grupo dominante colocado como absoluto, como tradição inquestionável e fundamental, enquanto qualquer variação desse pensamento era considerada perigosa e algo a ser combatido. É sempre, porém, o próprio grupo dominante que se coloca como tal e, desta maneira, coloca o outro (qualquer que se difere desse grupo) como secundário ou "anômalo". Segundo Beauvoir, "nenhum sujeito se define imediata e espontaneamente como o inecessencial; não é o Outro que se definindo pelo Outro define o Um; ele é posto como Outro pelo Um definindo-se como Um. Mas para que o Outro não se transforme no Um é preciso que se sujeite a esse ponto de vista alheio" (BEAUVOIR, 1949, p. 16).

Essa imposição de uma neutralidade no ambiente educacional coloca todos aqueles envolvidos no processo de ensino e aprendizagem não apenas submetidos ao ponto de vista do grupo social dominante, mas também os contempla como massa e não como indivíduos. Assim, para que se tire o Outro do lugar de Outro e se coloque em questão tal sistema é necessário, antes de tudo, reconhecer os indivíduos como seres únicos e subjetivos, que são fruto de seu contexto social e de diversos outros fatores que contribuem para a construção da sua individualidade. Desta maneira é impossível que sejam colocados como imparciais ou dentro de um padrão de normalidade e neutralidade, pois, sendo cada indivíduo único e peculiar, o neutro e o normal inexistem.

Assim, um ensino que refuta essa visão de educação que privilegia uns em detrimentos de outros é um ensino que contempla o ser integralmente, que valoriza sua história, seu contexto, seus pensamentos e características individuais, dando a ele a capacidade de se afirmar como indivíduo no meio social e coletivo no qual está 
Conceição | Conception

Revista do Programa de Pós-Graduação em Artes da

Cena, Universidade Estadual de Campinas

Performing Arts Graduate Program Journal, University of

Campinas

inserido. A educação é, desta maneira, um caminho para o empoderamento do indivíduo e reconhecimento da diversidade presente em um coletivo.

No âmbito da educação em dança esse empoderamento acontece de diversas maneiras: quando se compreende o corpo como fenômeno intrínseco ao indivíduo, não dissociado dos outros aspectos que constituem o ser; quando a individualidade característica dos corpos - sejam elas estéticas, estruturais, cinestésicas etc. - e dos sujeitos envolvidos são aceitas e acolhidas no coletivo, sem hierarquizações e, principalmente, quando o indivíduo se torna capaz de fazer do movimento a sua voz, o seu discurso, a expressão de si e daquilo que quer dizer ao mundo.

Tais questões foram fortemente abordadas pelos artistas que fizeram parte do surgimento da dança pós-moderna. Com o intuito de quebrar as amarras da tradição clássica e moderna, os pós-modernos romperam com ideais de corpo, promoveram a liberdade de expressão por meio do movimento, aproximaram a arte do cidadão comum e construíram uma nova visão de comunidade. Segundo Isabelle Nogueira,

No campo das artes, o pós-guerra europeu e americano também trouxe mudanças nos modelos estruturais de trabalho. Um exemplo marcante destas mudanças aconteceu, a partir de 1963, em Greenwich Village, na cidade de Nova York, transformando a arte e seu papel na vida americana, e tornando-se marco de outras muitas transformações no mundo da arte. Grupos de artistas afrouxavam a estrutura social e cultural vigente ao fundir vida pública e privada, trabalho e diversão, a arte e a experiência comum. Este movimento, segundo Bannes (1999), estava formando a base multifacetada de uma cultura alternativa que florescia na contracultura do final da década de 1960, que semearia os movimentos de arte da década de 1970 e moldaria os debates sobre o pós-modernismo da década de 1980 em diante. Este movimento artístico e político foi exemplo e, possivelmente, gênese de uma forma de organização biopolítica de coletivos de dança, pois através das novas noções de arte, comunidade, democracia, trabalho e diversão, corpo, papel das mulheres, natureza e tecnologia, surgiu uma experiência profícua no Judson Dance Theater, por exemplo (NOGUEIRA, 2007).

O Judson Dance Theater era uma instituição coletiva de coreógrafos livremente organizada que incluiu não apenas artistas da dança, mas também 
Conceição | Conception

Revista do Programa de Pós-Graduação em Artes da

Cena, Universidade Estadual de Campinas

Performing Arts Graduate Program Journal, University of

Campinas

aqueles advindos de outras linguagens artísticas. O grupo realizou seu primeiro concerto em 6 de julho de 1962 no espaço da Judson Church e, a partir disso, passou a reunir-se semanalmente, com sessões abertas a qualquer pessoa que quisesse delas participar ou assistir (BANES, 1999).

Os artistas do Judson Dance Theater criaram uma dança difusa e transgressora, modificando preceitos estéticos, negando o corpo impostado e treinado por técnicas tradicionais e buscando o movimento mais próximo do que seria natural ou cotidiano. Partindo da premissa de que todo e qualquer movimento é dança, propuseram não a criação de um novo padrão ou de uma nova técnica, mas a quebra de todos esses padrões e a valorização da liberdade individual do artista, ampliando as possibilidades de criação e expressão por meio da dança. Segundo Muniz,

\begin{abstract}
A partir da produção de dança do Judson, percebe-se o fim da "beleza", da "forma", do valor supremo e sublime da dança como arte. Desarticula-a atacando a própria definição de dança e revela o que lhe foi estranho até então, utilizando-se de todas as possibilidades para considerá-la poética sob todos os ângulos, entregando-se a sucessivas impressões e as traduzindo todas ao mesmo tempo. A dança pós-moderna não apresenta um momento de organização, uma lógica, um centro, e a concepção e a criação se dá na experimentação, e não antes dela. Um desejo de liberdade estética, de liberdade no corpo, é, portanto, o fim da imposição de um estilo artístico, é o fim do engessamento estético e técnico da dança (MUNIZ, 2011, p. 76).
\end{abstract}

Tais transformações no pensamento a respeito da arte da dança promoveram a valorização do corpo real, comum, cotidiano e não idealizado, sustentando "a concretude, intimidade e desalinhamento do corpo humano não só como aceitáveis, mas como belos" (BANES, 1999) e acolhendo a diversidade de corpos, sem a imposição de um padrão de estética, técnica ou de movimentação. Desta maneira, eram aceitos no grupo não apenas bailarinos ou artistas, mas todos aqueles que se interessassem e tivessem disponibilidade para participar das investigações. Assim, criaram um ambiente de pluralidade e democracia do corpo e do movimento, 
Conceição | Conception

Revista do Programa de Pós-Graduação em Artes da

Cena, Universidade Estadual de Campinas

Performing Arts Graduate Program Journal, University of

Campinas

ampliando as possibilidades de criação e composição, além de promover os ideais políticos de não discriminação e de igualdade, dado que artistas e não artistas atuavam juntos, sem uma estrutura hierárquica.

Segundo Sally Banes (BANES, 1999), os ideais de democracia e igualdade adquiriram diversas formas na vida artística do Judson, entre as quais é possível citar o estilo das obras que envolviam de forma direta o espectador, o conteúdo político explícito da própria arte e a estrutura coletiva de apresentação. Além disso, as diversas "instituições cooperativas e alternativas [...] convertiam a própria criação de arte num processo de criação da comunidade, com a responsabilidade e a promessa de autonomia local". Dentro desse contexto surgiram também as redes informais de amizade e associações formais que deram origem a vínculos artísticos e interdisciplinares.

Dessa maneira, é possível afirmar que o movimento do Judson Dance Theater foi significativo não apenas no contexto artístico, mas também no âmbito político e social. Foi de grande relevância nas lutas das minorias sociais, como no movimento negro e feminista. Sobre este, pode-se observar que

[...] na comunidade construída em torno do Judson Dance Theater, as mulheres emergiram [...] para criar um espaço [...] em que pudessem tomar a direção e ser artistas criativas, não de um modo protoseparatista, mas em concerto com seus colegas homens. [...] Era esta uma transformação importante pois, ao assumirem o papel de artistas sérias, essas bailarinas legitimaram as mulheres como artistas em outros campos, nas duas décadas seguintes. [...] Na década de 1970, a segunda onda do feminismo produzira uma geração de mulheres artistas que se dirigiram para as artes performáticas, para a pintura e para a direção de cinema, assim como para a dança e o teatro, algumas diretamente inspiradas pelos exemplos específicos dessas bailarinas do Judson e algumas que se beneficiaram, inconscientemente, das brechas que essas mulheres produziram no mundo da arte da década de 1960 (BANES, 1999, p. 102).

Trazendo para o contexto da história da dança no Brasil, foi muito importante a influência do bailarino, coreógrafo, professor e pesquisador Klauss Vianna na construção de uma técnica e de uma visão de dança que levasse o foco do trabalho 
Conceição | Conception

Revista do Programa de Pós-Graduação em Artes da

Cena, Universidade Estadual de Campinas

Performing Arts Graduate Program Journal, University of

Campinas

corporal para o autoconhecimento, rejeitando padrões externos ou importados e repetições cegas da tradição da dança clássica. Klauss voltou-se para os aspectos humanos do fazer artístico da dança: as relações, a subjetividade e a estrutura anatômica e fisiológica do corpo em movimento. Segundo Alvarenga, a partir da base do balé clássico,

com suas reflexões e pesquisas, procurou retirar da técnica clássica todo formalismo que, segundo ele, tornava-a um método artificial, distanciando-a dos seus fundamentos básicos, além de dificultar a relação ensino-aprendizagem, uma vez que, para ele, algo "se perdeu na relação entre professor e aluno e que faz da sala de aula um espaço pouco saudável". Em suas reflexões sobre o ensino de dança propôs mudanças no comportamento de professores por ele vistos como "brutais"; sugere, então, maior liberdade para a expressão individual do aluno, o que ampliou o alcance de seu trabalho para além do balé, alcançando também o teatro e pessoas não ligadas especificamente às artes do espetáculo. Seu trabalho teve influência sobre várias gerações de bailarinos, professores de dança, coreógrafos, atores e pesquisadores do movimento, como Marilene Martins, Isabel Costa, Dudude Herrmann, Marília Pêra, Marco Nanini, Zélia Monteiro, Eduardo Costilhes, Neide Neves, Tônia Carreiro, dentre outros. (ALVARENGA, 2009, p. 18)

O autor esclarece que alguns dos pontos principais defendidos por Klauss e para os quais ele se voltou em suas pesquisas seriam a brasilidade - tudo aquilo que é próprio da cultura nacional -, a originalidade - o frescor da criação que é fruto da experiência individual do sujeito-bailarino, a qualidade íntima - aquilo que é próprio do indivíduo, que se destaca por ser seu e intransferível - e a qualidade técnica - não como uma formatação do movimento, mas como um fruto do desenvolvimento e refinamento da consciência corporal. Pode-se dizer que

Klauss Vianna arriscou-se em um caminho próprio, com uma proposta de dança que trazia inovações, que comportava rupturas. Caminho que percorreu de maneira um tanto solitária, naquele momento. Assumiu riscos, e com isso colheu sucessos, produziu fracassos, teve adeptos e também críticos (ALVARENGA, 2009, p. 149). 
Conceição | Conception

Revista do Programa de Pós-Graduação em Artes da

Cena, Universidade Estadual de Campinas

Performing Arts Graduate Program Journal, University of

Campinas

Umas das principais mudanças que Klauss propôs ao ensino da dança seria o abandono de uma técnica autoritária, "militar" e importada, que exige do aluno a reprodução de um padrão externo ao próprio corpo e ao contexto na qual se insere. É necessário que o aluno tenha a liberdade de expressar-se e fazer do trabalho corporal um caminho para conhecer o próprio corpo, sua fisiologia, seus espaços, suas estruturas e, principalmente, sua subjetividade, podendo assim reconhecer-se como indivíduo no fazer artístico da dança. Em outras palavras,

Uma sala de aula não pode ser esse modelo que vemos, no qual a disciplina tem algo de militar, não se pergunta, não se questiona, não se discute, não se conversa. [...] A dança não se faz apenas dançando, mas também pensando e sentindo: dançar é estar inteiro. Não posso ignorar minhas emoções em uma sala de aula, reprimir essas coisas todas que trago dentro de mim (VIANNA, 2005, p. 32).

Além disso, enfatiza que o espaço da sala de dança não deve findar-se em si mesmo, levando a um distanciamento da vida, mas deve estabelecer uma relação com aquilo que acontece fora dela. É preciso que o ser humano que existe no bailarino esteja atento a tudo o que acontece nas ruas, na política, no mundo, pois "é impossível dissociar vida de sala de aula" (VIANNA, 2005).

Para Klauss, "a arte é, antes de tudo, um gesto de vida" e "um artista é, antes de tudo, um indivíduo" (VIANNA, 2005). Assim, a partir deste ponto de vista, para que o fazer artístico da dança faça sentido é preciso que ele se relacione diretamente com a vida cotidiana, que sirva como um caminho para a reflexão, para evolução pessoal, para o autoconhecimento e transformação social e política. Nas palavras do artista,

Quando uma técnica artística não tem um sentido utilitário, se não me amadurece, não me faz crescer, se não me livra de todos os falsos conceitos que me são jogados desde a infância, se não facilita meu caminho em direção ao autoconhecimento, então não faço arte, mas apenas um arremedo de arte (VIANNA, 2005, p. 72). 


\section{Conceição | Conception}

Revista do Programa de Pós-Graduação em Artes da

Cena, Universidade Estadual de Campinas

Performing Arts Graduate Program Journal, University of

Campinas

Por meio desta breve contextualização histórica é possível concluir que a dança não é apenas fruto de seu contexto sociopolítico, mas é também agente transformador do mesmo. Contrariamente ao que propõe o Programa Escola Sem Partido, entendemos que convicções, sejam elas dos pais ou das próprias crianças e adolescentes em sala de aula, precisam sempre ser analisadas; o direito à perpetuação de convicções, tal como se pode depreender da redação "os pais têm direito a que seus filhos recebam a educação religiosa e moral que esteja de acordo com suas próprias convicções", é uma falácia sobre a qual é necessário refletir, e a dança é um lugar potente para esta reflexão, à medida que promove sensibilidade, autoconhecimento e, por decorrência, empoderamento, ao colocar a pessoa como sujeito, com seu corpo - corpo este que subjaz à vida de todos, tanto no aspecto moral quanto no religioso, quando este existe. A questão colocada no texto do programa Escola Sem Partido, “Que fazer para coibir esse abuso intolerável da liberdade de ensinar?", é perigosa à medida que traz, em uma única oração, palavras como coibição e intolerável, sugerindo que professores devem ser cerceados em sua liberdade de ensinar como se isso não tivesse relação com a liberdade do aluno de aprender.

Assim, inserido em um contexto educacional que promova a liberdade de expressão e que valorize a individualidade e a diversidade presentes no coletivo, é possível afirmar que o ensino da dança pode ser uma ponte para o empoderamento do indivíduo, para a formação de uma consciência social e política e para a construção de uma sociedade mais justa e democrática. 
Conceição | Conception

Revista do Programa de Pós-Graduação em Artes da

Cena, Universidade Estadual de Campinas

Performing Arts Graduate Program Journal, University of

Campinas

\section{Um ensino de dança empoderador: enfrentando os desafios da formação híbrida contemporânea em dança}

\section{Como a sociedade enxerga a dança}

Como nos explica Jill Green em seu artigo “Emancipatory Pedagogy?: Women's Bodies and the Creative Process in Dance" (2000), a criatividade, ferramenta essencial do trabalho artístico, tem sido tópico de discussão ao longo dos anos. Uma visão antiga e ainda predominante na sociedade é a de que a criatividade é um dom, uma virtude inata com a qual indivíduos especiais, privilegiados, nascem. Apenas esses indivíduos naturalmente criativos seriam capazes de se tornar artistas, transformando seu potencial em ação, produto. Ao longo dos anos, diversos autores têm posto em cheque essa visão e criado novas teorias da criatividade. Psicanalistas, como Freud, explicaram a criatividade como uma atividade neurótica ou disfuncional; teóricos humanistas e ambientalistas acreditavam, nos anos 1960 e 1970, que a criatividade era um processo humano natural e parte de toda vida saudável e plena - alguns defendendo que todos poderiam ser criativos. Teorias mais recentes, como a de Livia Pohlman (POHLMAN, apud GREEN, 2000, tradução livre), têm examinado a criatividade sob uma perspectiva social, segundo a qual "[a criatividade] pode ser considerada um processo social, dramaticamente afetado pelo ambiente social e instituições, em vez de simplesmente um traço psicológico inerente a indivíduos" (p. 6) ${ }^{6}$. Green exemplifica:

Eu descobri que durante um projeto de criação que eu dirigi, as mulheres, em comparação com os homens, tendiam a ver o processo criativo através de lentes sociais. As definições de criatividade não estavam limitadas a um contexto individual. Por exemplo, quando uma estudante entrou em uma loja de artigos de dança, foi dito a ela que ela era muito grande para comprar um collant para o projeto; isso afetou seu processo criativo. Outra estudante, que sofria com um estupro passado, se sentiu restringida durante o projeto e indicou

6 "[creativity] may be considered a social process, dramatically affected by social environments and institutions, rather than simply a psychological trait inherent in individuals" (p. 6). 
Conceição | Conception

Revista do Programa de Pós-Graduação em Artes da

Cena, Universidade Estadual de Campinas

Performing Arts Graduate Program Journal, University of

Campinas

que o estupro afetou sua capacidade de ser criativa. Definir criatividade com apenas um contexto individualista se tornou problemático $^{7}$ (GREEN, 2000, p. 5, tradução livre).

Assim como a criatividade e o labor do artista, a ideia que a sociedade faz de dança e do bailarino está ainda bastante atrasada em relação às teorias e práticas mais recentes de corpo e movimento. Dentre alguns estereótipos bastante divulgados estão a ideia da dança como uma arte restrita a indivíduos privilegiados, que nasceram, além de criativos, com corpos belos, longilíneos, e uma capacidade inata de reproduzir movimentos virtuosos. Essa noção bastante perniciosa provém ainda da figura das bailarinas clássicas, consideradas etéreas, virtuosas, e em muitos ambientes do mundo da dança esse ideal é considerado atingível através de esforços e sacrifícios diários. Na prática isso se traduz em bailarinos que se sujeitam a rotinas e treinamentos deformadores, prejudiciais à saúde mental e física, e que se veem irremediavelmente lesionados ainda jovens.

A dança moderna e, mais tarde, a contemporânea, vêm para desafiar esses modelos autoimpostos de beleza, ressignificando a dança, o movimento e os corpos que os tornam concretos. Surgem a educação somática, trabalhos de conscientização corporal, improvisação, novas plataformas de criação e tecnologias de corpo. No imaginário popular, entretanto, a imagem da bailarina perfeita, sem frieira, primeiro namorado ou problemas na família (como compôs Chico Buarque em sua Ciranda da Bailarina) persiste. Podemos então nos perguntar por que há esse enorme abismo entre o imaginário popular e as práticas de vanguarda da dança, e como isso afeta os bailarinos que se formam e atuam nesse contexto de contradições.

\footnotetext{
7 "I found that during a particular creative project that I directed, the women, as compared to the men, tended to view the creative process through a social lens. Definitions of creativity were not limited to an individual context alone. For example, when one student entered a dance supply store, she was told she was too large to purchase a leotard for the project; this affected her creative process. Another student, who suffered from a past rape, felt restricted during the project and indicated that the rape had affected her ability to be creative. Defining creativity within an individualistic context alone became problematic".
} 
Conceição | Conception

Revista do Programa de Pós-Graduação em Artes da

Cena, Universidade Estadual de Campinas

Performing Arts Graduate Program Journal, University of

Campinas

\section{Desafios da formação em dança}

Foucault enxerga os corpos como efeito da cultura na qual vivemos, que acaba por transformar esses corpos-indivíduos em local-objeto de manipulação e controle político. Paulo Freire complementa a ideia desse controle externo e coletivo sobre o interno e individual, dizendo:

\footnotetext{
Os oprimidos, tendo internalizado a imagem do opressor e adotado suas linhas de atuação, têm medo da liberdade. A liberdade requeriria deles rejeitar essa imagem e preencher o seu lugar com autonomia e responsabilidade. Liberdade se adquire pela conquista, não como um presente. Ela deve ser buscada constantemente (FREIRE, apud VALOURA, 2005, p. 3).
}

O que isso implica, para a dança, é uma grande dependência do bailarino em relação a professores, coreógrafos, diretores e outras figuras de autoridade. O bailarino frequentemente transfere a responsabilidade sobre seu corpo, sua saúde e até mesmo sua identidade artística a uma referência externa a si. Há um distanciamento do corpo e da mente, da identidade do ser com sua dimensão corpórea, que se torna apenas instrumento de manipulação - um instrumento imperfeito, que necessita ser moldado para atender às exigências técnicas de trabalhos específicos.

As figuras de autoridade que seriam a referência desses bailarinos, entretanto, também estão pulverizadas. Louppe explora isso em “Corpos Híbridos” (2000), em que discute a formação dos bailarinos na contemporaneidade e as consequências desse tipo de formação.

Até os anos 1980, as linhagens de dança (e de corpos dançantes) seguiam conjuntos de princípios estéticos e filosóficos de grandes criadores, cujos referenciais simbólicos os próprios corpos dos bailarinos portavam. No final dos anos 1980, entretanto, iniciou-se um movimento de negação da herança, de livrar-se do pesado fardo das tradições em busca do sonho de uma dança sem raízes, ou cujas raízes não 
Conceição | Conception

Revista do Programa de Pós-Graduação em Artes da

Cena, Universidade Estadual de Campinas

Performing Arts Graduate Program Journal, University of

Campinas

fossem reconhecidas. Ao início do processo de mistura de referências se falava em mestiçagem, ou seja, os sujeitos não eram modificados em sua estrutura, mas enriquecidos pela acumulação de diferentes heranças culturais. Havia a ideia de pertencimento a grupos identitários e de alteridade, troca, diálogo eventual entre eles. Esses modelos ainda persistem, mas o que surgiu atualmente, por outro lado, é identificado por Louppe como hibridação.

Segundo Dena David (DAVID, apud LOUPPE, 2000), os corpos híbridos são aqueles oriundos de formações diversas, elementos díspares, até mesmo contraditórios entre si, "sem que lhe sejam dadas as ferramentas necessárias à leitura de sua própria diversidade" (p. 32). A mistura de materiais, nesse caso, torna-se superficial e ilusória, pois os corpos dos bailarinos não foram tocados. Isso quer dizer que, apesar de ser capaz de mimetizar os diversos estados corporais exigidos pelas diferentes referências, esse corpo híbrido não se apropria do conceito de corpo que existe por trás de cada uma delas, o seu trabalho de tônus corporal etc. O corpo não compreende nem vive verdadeiramente cada uma dessas referências, pois se preocupa em apreendê-las rapidamente, em prazos de tempo meramente conjunturais. Com essa pulverização dos dados a dança se torna formal, fragmentada, superficial, produzindo obras pontuais, destituídas de permanência, afastadas do ideal de "obra de arte completa" que, segundo Louppe, a coerência das referências parecia trazer por si só.

O híbrido, portanto, não se situa em lugar nenhum. É isolado e atípico, resultado de uma combinação única e acidental. Torna-se uma relação não entre raças, mas entre "espécies" (concepções de corpo) incompatíveis. Com a hibridação deixam de existir zonas reconhecíveis de experiência corporal e de construção do sujeito; o corpo é portador dos estigmas (marcas) sem que sua essência, substância imaginária, seja verdadeiramente afetada. Trata-se de um acúmulo de referências sem que nenhuma delas seja verdadeiramente apreendida em sua estrutura interna, mas sim escolhidas arbitrariamente por sua aparência, como se o corpo já não fosse um sistema de visão e pensamento relacional e íntegro. Apesar disso a hibridação é, 
Conceição | Conception

Revista do Programa de Pós-Graduação em Artes da

Cena, Universidade Estadual de Campinas

Performing Arts Graduate Program Journal, University of

Campinas

hoje em dia, o destino do corpo que dança, tanto pelas exigências das criações coreográficas quanto pela elaboração da própria formação, feita através de cursos de curta duração, workshops, pluralidade de referências e exigências simultâneas.

Esse processo nada sutil de fragmentação das referências gera respostas diferentes. Alguns bailarinos buscam seu lugar, um refúgio onde "tomar corpo", enquanto criadores mais sensíveis buscam justamente encontrar uma fonte íntima e comum de adesão entre seus intérpretes. Há, nesse caso, a reivindicação de um corpo autônomo, independentemente dos modos vigentes de representação e das leis do mercado do espetáculo. Outra vertente propõe, ao contrário, confiar nas promessas da incerteza e na vontade de aceitar a história, aprendendo a jogar com as feridas de um corpo que não se constitui a partir de uma consciência contínua de si. O que Louppe propõe não é uma hierarquização entre essas diferentes correntes, tampouco conjurar essas fragilidades do corpo híbrido, mas pensar sobre elas e decifrar o sentido que elas escondem.

A autora ainda afirma que pode existir, sim, um "corpo eclético" se as condições forem favoráveis, ou seja, se houver a possibilidade de transitar descomprometidamente entre opções diferentes. Esse "passeio", na medida do possível, deve acontecer no espírito e no corpo do bailarino, porém sem impedir a construção de um ser crítico, pensante. A sua relação com o mundo se dá, portanto, mediante uma gama complexa de mediações, da aquisição consciente das ferramentas simbólicas através de uma lenta impregnação "epidérmica", em uma longa aprendizagem.

Podemos dizer, portanto, que uma saída para solucionar a desconexão entre corpo e mente do bailarino híbrido vai muito além de uma simples negação das múltiplas referências. É necessário que o bailarino encontre, dentro de si, uma identidade e senso crítico capaz de filtrar e transformar essas informações conflitantes, absorvendo-as ou não. Com esse objetivo, novamente evocamos Paulo Freire, que ao trazer o termo "empoderamento" para o Brasil, o define: "a pessoa, grupo ou instituição empoderada é aquela que realiza, por si mesma, as mudanças e 
Conceição | Conception

Revista do Programa de Pós-Graduação em Artes da

Cena, Universidade Estadual de Campinas

Performing Arts Graduate Program Journal, University of

Campinas

ações que a levam a evoluir e se fortalecer" (FREIRE, apud VALOURA, 2005, p. 2). O empoderamento implica, portanto, a capacidade de viver essas contradições e ainda ser capaz de tomar as melhores decisões para o fortalecimento de si, pautadas na experiência e necessidade pessoal, até mesmo confrontando as figuras de autoridade quando necessário.

\section{O empoderamento por meio da dança}

Se o professor é figura de autoridade e, portanto, atua como referência externa e fonte de opressão, seria possível empoderar bailarinos pela educação? Schiavo e Moreira escrevem, sobre o empoderamento cunhado por Paulo Freire:

Implica, essencialmente, a obtenção de informações adequadas, um processo de reflexão e tomada de consciência quanto a sua condição atual, uma clara formulação das mudanças desejadas e da condição a ser construída. A estas variáveis, deve somar-se uma mudança de atitude que impulsione a pessoa, grupo ou instituição para a ação prática, metódica e sistemática, no sentido dos objetivos e metas traçadas, abandonando-se a antiga postura meramente reativa ou receptiva (SCHIAVO, MOREIRA, apud VALOURA, 2005, p. 2).

O que isso significa é que não é possível, para um professor, ser um veículo externo de empoderamento de seus alunos: eles é que devem se empoderar, tomar o controle de suas vidas mediante uma iniciativa interna. Paulo Freire considera, ainda, que

O grande problema está em como poderão os oprimidos que 'hospedam' o opressor em si, participarem da elaboração como seres duplos, inautênticos da pedagogia de sua libertação. Somente na medida em que se descobrem 'hospedeiros' do opressor poderão contribuir para o partejamento de sua pedagogia libertadora (FREIRE, 1970, p. 17).

Implica-se, portanto, um duplo papel que o professor pode exercer, no esforço de promover o empoderamento de seus alunos: ele deve fornecer ao aluno as informações adequadas para que haja "um processo de reflexão e tomada de 
Conceição | Conception

Revista do Programa de Pós-Graduação em Artes da

Cena, Universidade Estadual de Campinas

Performing Arts Graduate Program Journal, University of

Campinas

consciência quanto a sua condição atual" (SCHIAVO, MOREIRA, apud VALOURA, 2005, p. 2), mas deve também permitir a esse aluno enxergar o opressor que há dentro dele, até mesmo se esse opressor for reflexo da própria figura do professor que tenta "libertá-lo".

Jill Green nos dá um exemplo prático dessa complicada dinâmica de poder. Ela desenvolveu um projeto de aulas com alunas universitárias no qual ela atuou como professora e diretora da apresentação final. O objetivo desse projeto era investigar o ensino de dança na universidade, desconstruindo modos de ensino tradicionais, opressivos aos corpos dos bailarinos, e descobrir novos caminhos, menos opressivos e mais conscientes. Ela buscava estudar quais eram as percepções corporais de estudantes de graduação em dança, e como suas experiências prévias na educação em dança influenciaram sua visão e tratamento do próprio corpo.

O projeto se desenrolou da seguinte forma: na primeira parte das aulas, as alunas eram expostas a variadas práticas somáticas, abordagens e métodos voltados para a consciência corporal, usados como estratégia para ajudar as estudantes a tomarem consciência de suas percepções corporais internas (práticas como Kinetic Awareness $^{R}$, Feldenkrais Awareness Through Movement, relaxamento progressivo, visualização e imagética, Ideokinesis, técnicas de respiração e outras abordagens corporais); na segunda parte das aulas, as participantes mergulhariam no processo criativo e trabalhariam na direção de uma performance de grupo, na qual elas pudessem extravasar as energias criativas que estavam sendo geradas durante as aulas.

Durante o processo de criação da performance, Green frustrou-se ao perceber que, embora as alunas tivessem diversas ideias de cenas e movimentos, elas nunca evoluíam para um "pensamento coreográfico completo", uma dramaturgia roteirizada. Além disso, os movimentos e cenas sugeridos eram sempre estéticos, "dançados", seguindo um modelo bastante tradicional de coreografia. Green decidiu, por fim, realizar um exercício no qual as bailarinas tinham que improvisar enquanto contavam suas "histórias de corpo" (situações vividas que afetaram sua 
Conceição | Conception

Revista do Programa de Pós-Graduação em Artes da

Cena, Universidade Estadual de Campinas

Performing Arts Graduate Program Journal, University of

Campinas

visão de corpo e de si). Ela pretendia que, dessa maneira, as alunas conseguissem se libertar de padrões e expectativas estéticas internalizadas, escutando apenas o que o corpo queria dizer. O exercício foi bem sucedido, gravado em vídeo, e as alunas ficaram satisfeitas com o que viram: um corpo mais focado, consciente; um corpo que fala sem o medo de ser escutado e julgado. Por fim, acabaram abandonando suas ideias anteriores de cenas e movimentos, assim como a sugestão de um "pensamento coreográfico completo"; enfrentaram as figuras de autoridade que estavam presentes tanto na professora quanto no público, e por fim decidiram desenvolver uma improvisação estruturada como resultado final do projeto. Em ponte com Paulo Freire, percebemos que foi a reflexão e tomada de consciência quanto à sua condição atual (estarem presas a padrões estéticos) que permitiu uma formulação das mudanças desejadas (permitir que seus corpos falassem), mudança de atitude e ação no sentido dos objetivos e metas traçadas (transformar o formato da apresentação final), abandonando-se a antiga postura meramente reativa ou receptiva (aceitar passivamente a sugestão de um "pensamento coreográfico completo").

A figura do professor foi, nesse exemplo, tanto figura de autoridade e fonte de opressão, quanto ferramenta para que o empoderamento dos alunos fosse possível. Foi somente por meio do exercício proposto pela professora que elas conseguiram se dar conta de suas limitações e lutar pela própria libertação. Um docente que trabalhe sempre receptivo às vozes dos alunos e, ao mesmo tempo, crítico de si mesmo, é capaz de servir como gatilho, catalisador do empoderamento de seus alunos.

Em uma linha de trabalho diferente, mas também empoderadora, temos o exemplo da professora Dra. Graziela Estela Fonseca Rodrigues, que desenvolveu o processo de formação em dança intitulado Bailarino-Pesquisador-Intérprete (BPI), resultado de sua própria vivência como bailarina e da experiência de anos dedicados à formação dos alunos do Curso de Graduação em Dança da Unicamp. Em seu livro “Bailarino-pesquisador-intérprete: processo de formação" (1997), Rodrigues conta como esse trabalho se iniciou: 
Conceição | Conception

Revista do Programa de Pós-Graduação em Artes da

Cena, Universidade Estadual de Campinas

Performing Arts Graduate Program Journal, University of

Campinas

\begin{abstract}
Na primeira fase, vivenciei a crise em relação ao meu conhecimento sobre dança, que incluía o trânsito nas áreas de dança clássica, moderna, contemporânea, de técnicas ligadas à dinâmica corporal e de técnicas de interpretação teatral.

Essa relação de crise não significou a rejeição dos conhecimentos anteriores, mas a sua reinterpretação a partir da interação com minhas descobertas pessoais e com os conhecimentos adquiridos nas pesquisas de campo sobre manifestações culturais brasileiras (RODRIGUES, 1997, p. 17).
\end{abstract}

Seus questionamentos iniciais foram gerados pela sensação de que havia uma dissociação entre sua formação híbrida, de diversos conteúdos formais apreendidos, que era bastante técnica e marcada pelo rigor da disciplina, e o ambiente interno da artista. “Uma grande porção de sensações e sentimentos não cabiam naquele corpo que eu construía. Afinal, o que era o meu corpo? O que era o corpo do outro instituído para ser o meu modelo?" (RODRIGUES, 1997). Fica evidente a recorrência de algumas questões: a dissociação do corpo como externo ao indivíduo, objeto de manipulação; a imposição de um modelo externo de movimentação; e a necessidade de descobrir e se apropriar deste corpo, empoderando-se como artista e ser humano. "Por fim as perguntas não respondidas se agruparam em uma só: Sou ou não uma intérprete? A rota indicava uma procura no interior da bailarina" (RODRIGUES, 1997). Essa busca pela deflagração do seu ambiente interno veio aliada a uma preocupação com a atividade criativa.

Guiada inicialmente pela intuição, ela iniciou um processo de pesquisa de campo com mulheres candangas de Brasília. Após três meses de intensa convivência diária com essas mulheres, ela voltou ao espaço da sala de dança e lá realizou laboratórios, conduzidos pelo diretor João Antonio de Lima Esteves:

No início o corpo não respondia, mas aos poucos foram emergindo registros emocionais, somatória do universo vivenciado na pesquisa de campo com a minha própria memória afetiva. O corpo foi assumindo várias sensações e configurações decorrentes das imagens de lugares vividos em campos e das imagens "desconhecidas" situadas em mim mesma. Estas imagens conjugadas apresentavam uma nova configuração de paisagem - espaço onde se desenvolvem 
Conceição | Conception

Revista do Programa de Pós-Graduação em Artes da

Cena, Universidade Estadual de Campinas

Performing Arts Graduate Program Journal, University of

Campinas

experiências de vida, que se instaurava no corpo (RODRIGUES, 1997, p. 19).

Essa descrição se assemelha à experiência vivida pelas alunas de Jill Green quando dançaram contando suas "histórias de corpo": suas mentes distantes das preocupações estéticas, entregues às imagens; as bailarinas entregues à escuta do corpo. Rodrigues desenvolveu sua pesquisa corporal até que a personagem que estava surgindo em seu corpo ganhou nome: Graça, e Graça ganhou um espetáculo, síntese de seu processo de criação. A partir de então, Rodrigues continuou a replicar esse processo, descobrindo em cada nova pesquisa de campo novos insights, aprofundamentos desse método criado. Em 1986, ela abriu mão de sua carreira como intérprete, vindo a desenvolver esta ideia de um processo no qual o bailarino não se encontra na condição de objeto, mas na condição de sujeito.

Na segunda fase do Processo de construção do bailarino-pesquisadorintérprete, desenvolvi o seguinte roteiro:

- autoquestionamento do bailarino sobre a sua relação com o corpo e com a própria dança;

- realização de experiências iniciais com manifestações culturais brasileiras em laboratório;

- contato direto do bailarino com as fontes em pesquisa de campo;

- retorno ao laboratório para articulação do trabalho criativo (RODRIGUES, 1997, p. 17).

Esse roteiro evidencia, novamente, o empoderamento de Paulo Freire: o autoquestionamento e as experiências com manifestações culturais brasileiras se configuram como processo de tomada de consciência do bailarino quanto à sua condição atual e consequente formulação das mudanças desejadas; o contato com as fontes de pesquisa em campo e os laboratórios de trabalho criativo representam uma mudança de atitude e ação no sentido dos objetivos e metas traçadas, resultando em um espetáculo fruto da união entre as experiências de campo e o ambiente interno do intérprete, no qual se abandona a antiga postura meramente reativa ou receptiva, e o intérprete "está inteiro em cada fragmento da cena, o conteúdo do espetáculo faz 
Conceição | Conception

Revista do Programa de Pós-Graduação em Artes da

Cena, Universidade Estadual de Campinas

Performing Arts Graduate Program Journal, University of

Campinas

parte dele. No entrelaçamento sujeito-personagem o bailarino não interpreta, mas vive no seu corpo a vida dimensionada pelo espetáculo, sem restrições" (RODRIGUES, 1997). Graziela Rodrigues respondeu, assim, à sua angústia inicial sobre a identidade do intérprete.

Além da resposta que procurava, aqui foi encontrado também um ponto de equilíbrio para a formação híbrida: um lugar de reconhecimento de si em meio às estéticas e aptidões técnicas variadas:

\begin{abstract}
A questão do bailarino-intérprete continua sendo o principal eixo de meu trabalho. São atributos do bailarino-intérprete a condição de estar liberto de estilos e técnicas, porém sem destituí-los. A instrumentalização do corpo deve criar condições para que o bailarino seja um "organismo vivo", pronto a responder aos conteúdos emergentes da realidade pessoal e da realidade que o cerca (RODRIGUES, 1997, p. 21).
\end{abstract}

Como estudante no Curso de Graduação em Dança da Unicamp, uma das autoras deste artigo teve a oportunidade de vivenciar o método BPI durante dois anos, nas disciplinas de Dança do Brasil I a IV. Sob a orientação da professora doutora Ana Carolina Lopes Melchert, em Dança do Brasil I, foi apresentada a diversas manifestações populares brasileiras e construiu um inventário do corpo; este foi um processo de tomada de consciência sobre sua história, seus primeiros contatos com a dança, as tradições de sua família, enfim: tudo que constitui sua identidade corporal. Junto à professora doutora Larissa Sato Turtelli, em Dança do Brasil II e III, estudou o folguedo do boi e a capoeira, respectivamente, e em Dança do Brasil IV realizou uma pesquisa de campo com o candomblé e a umbanda. Todos essas pesquisas foram aliadas a processos criativos de exploração das imagens que emergiam.

Com cada uma dessas manifestações descobriu aspectos sobre os quais não estava consciente; emergiam em sua mente e seu corpo imagens desconhecidas ou pouco reconhecidas, com uma grande força interna - eram imagens de poder que lhe 
Conceição | Conception

Revista do Programa de Pós-Graduação em Artes da

Cena, Universidade Estadual de Campinas

Performing Arts Graduate Program Journal, University of

Campinas

permitiam uma livre manifestação artística, na qual havia pouca preocupação com julgamentos de estilo. É claro que um processo de empoderamento é longo e gradual, e as barreiras a serem superadas são inúmeras. "Liberdade se adquire pela conquista, não como um presente. Ela deve ser buscada constantemente" (FREIRE, apud VALOURA, 2005, p. 3). Isso significa que realizar um trabalho de dança empoderador não é suficiente para a libertação plena do indivíduo. Após o contato com o BPI, sentiu que empoderou-se em muitos aspectos, ciente de não ser possível ficar completamente livre do opressor que existe em si e nos outros, visto que a busca da liberdade é um processo contínuo.

\section{Qual é a dança que empodera?}

Vimos que a dança pode ser tanto ferramenta de opressão e sufocamento das individualidades quanto ferramenta de empoderamento. Assim, qual é a dança que empodera? Quais são as ferramentas que um professor de dança pode utilizar no empoderamento de seus alunos?

Jill Green defende o processo criativo somático (uso aliado da educação somática e da atividade criativa) como uma "força cultural subversiva", de empoderamento e enfrentamento da autoridade. Guiadas pelas práticas somáticas, as bailarinas são capazes de escutar seus corpos, descobrirem e se reapropriarem deles e, por meio da atividade criativa, enfrentar as figuras de autoridade, adquirindo liberdade criativa.

Já no trabalho de Graziela Rodrigues, os intérpretes descobrem dentro de si imagens desconhecidas (escuta do corpo), que emergem após a pesquisa de campo. Por meio do eixo "Incorporação da Personagem", eixo principal de seu trabalho, o bailarino-intérprete assume um “corpo imaginário, 'como se não fosse o dele', gerando uma liberdade de expressão e uma permissividade na dança de experimentar a fala e o canto, sem a preocupação de responder a padrões 
Conceição | Conception

Revista do Programa de Pós-Graduação em Artes da

Cena, Universidade Estadual de Campinas

Performing Arts Graduate Program Journal, University of

Campinas

convencionados" (RODRIGUES, 1997). Por via corporal emerge um enfrentamento das figuras opressoras de autoridade, situadas dentro de si e nos outros.

Em ambos os processos o bailarino ganha autoria sobre seu soma e sua atividade criativa, se empodera e se torna capaz de receber, filtrar e transformar as influências e direcionamentos externos sobre seus corpos. Transfere-se a autoridade e a responsabilidade sobre o corpo daquele que é alheio a ele para aquele que o vive de fato; do outro para si. Não cabe mais ao professor, coreógrafo, diretor, médico ou qualquer autoridade externa a decisão final sobre o corpo do aluno, bailarino, paciente ou pessoa em situação de subordinação. Transforma-se, portanto, a sensação de impotência ou confusão frente aos direcionamentos externos, frente à formação corporal híbrida: é gerada uma síntese - ponto de equilíbrio - através do próprio soma.

Se dois processos com metodologias tão diferentes geram resultados parecidos, o que torna um trabalho de dança empoderador? Acreditamos que um pensamento comum una esses dois trabalhos: em ambos há um processo de autodescoberta do bailarino, escuta do próprio corpo, que se desdobra na pesquisa da própria individualidade, construção de uma identidade corporal. Esse processo não é exclusivamente racional ou corporal: ele é fruto e síntese das experiências de vida que se ancoram e se manifestam no corpo-mente. Para que essas experiências possam emergir, a orientação de um docente libertário e crítico de si se faz necessária: ele é capaz de fornecer as informações adequadas para o processo de tomada de consciência, e de criar um ambiente propício para que as particularidades de cada aluno se manifestem - um ambiente de aceitação e valorização da experiência real, desprovido (o máximo possível) de expectativas estéticas e julgamentos de estilo. Uma vez que o aluno se conscientiza, torna-se capaz de enxergar o opressor dentro de si, descobre a própria identidade e decide reapropriar-se de seu corpo. O processo criativo vem, então, como ação concreta de mudança do seu contexto: é através da expressão artística que o bailarino enfrenta as 
Conceição | Conception

Revista do Programa de Pós-Graduação em Artes da

Cena, Universidade Estadual de Campinas

Performing Arts Graduate Program Journal, University of

Campinas

figuras de autoridade e consolida seu processo de empoderamento, em busca da própria liberdade.

\section{Corpo perfeito, eixo deslocado}

\section{O corpo no processo de desempoderamento}

Quando falamos em empoderamento, termo utilizado por Paulo Freire, visualizamos, segundo a definição deste autor, o processo de conquista por informações e práticas que levem à autonomia intelectual e crítica do indivíduo na sociedade, mais precisamente do indivíduo oprimido socialmente, do indivíduo que foi desempoderado em determinado momento da história. Buscando na história do corpo a origem deste desempoderamento, sob a perspectiva da dança, encontramos seus grandes princípios desencadeadores no processo de industrialização:

\footnotetext{
A classe dominante conduz através das etapas de produção todos os corpos de que dispõe, corpos também mutilados, cujo movimento a industrialização desenfreada fragmentará em módulos de intervenção parcelares e repetitivos, selando o fim de um corposujeito global, rico em múltiplas redes relacionais com o mundo e consigo próprio (LOUPPE, 2012, p. 57).
}

Como Louppe nos apresenta, a industrialização provocou diversas mudanças no corpo e na identidade dos sujeitos, que deixaram de ser sujeitos e passaram a ser partes integrantes da máquina industrial. Durante a implementação da industrialização, ocorreram transformações no eixo da vida social que alteraram o modo de vida das pessoas, trazendo diversas mudanças tecnológicas que interferiram na forma como o tempo passou a ser vivido por elas. Essas transformações trouxeram uma nova forma de divisão do trabalho, gerando mudanças na pirâmide social; aumentaram a exigência de carga horária para o trabalho, transformando a demanda energética de modo a elevar a média de 
Conceição | Conception

Revista do Programa de Pós-Graduação em Artes da

Cena, Universidade Estadual de Campinas

Performing Arts Graduate Program Journal, University of

Campinas

rendimento exigido por parte dos trabalhadores. Essas mudanças que ocorreram no mundo sedimentaram-se no corpo tornando-se mudanças internas, modificando a forma de se relacionar com o próprio corpo, o que recebe um destaque dentro do campo da dança, cujos modos de trabalho são predominantemente pensados a partir do próprio corpo.

O corpo-sujeito, aquele que se recusa a ferir-se em nome de algo, que tem autonomia sobre si, que responde de maneira crítica, em decorrência deste processo dá lugar ao que Foucault denomina “corpo-objeto" (FOUCAULT, 1977). Analisando a importância do corpo que foi o meio para que o trabalho da industrialização ocorresse, podemos nos deslocar para o universo histórico da dança e verificar como essas mudanças ocorreram dentro desta, como esse corpo-objeto percorreu essa área, e como foi que, percebendo tal fato, buscou-se um caminho para resgatar esta autonomia através do corpo.

Do ballet clássico à dança moderna, um corpo desempoderado versus uma busca por um empoderamento

Projetando este corpo-objeto, obediente, “dócil" (FOUCAULT, 1977) no ambiente da dança, visualizamos um corpo que responde imediatamente sem tempo nem ferramentas para reflexão; imita movimentos transmitidos visualmente; de maneira superficial apreende o movimento e, mesmo antes de interiorizá-lo, é capaz de reproduzi-lo. Nesta dinâmica, tomamos como exemplo o que acontece no ballet clássico, em que o bailarino copia movimentos, em que há a divisão entre as tarefas de criar e interpretar, há um coreógrafo que cria mentalmente os passos a serem executados, e aquele que os executa sem maiores questionamentos. Esse processo, na arte da dança, gera um deslocamento do eixo do corpo no sentido de uma projeção perfeita de corpo, de pessoa, de nível e rendimento, que vai de fora para dentro, ou nem isso, de fora para fora, de forma que um bailarino, por exemplo, encare suas práticas corporais como uma corrida em busca de um corpo ideal, de uma dança 
Conceição | Conception

Revista do Programa de Pós-Graduação em Artes da

Cena, Universidade Estadual de Campinas

Performing Arts Graduate Program Journal, University of

Campinas

perfeita, que se finaliza por adquirir determinadas técnicas supervalorizadas no mercado de trabalho.

O processo de distanciar-se do centro individual para buscar um padrão de perfeição encaminhou, pouco a pouco, e cada vez de forma mais exagerada, o fazer artístico a um enfoque voltado à sua dimensão técnica, à sua execução. Neste contexto, o profissional da dança trabalha para que suas linhas sejam idênticas ao padrão de beleza da dança clássica, ainda ícone desta visão tecnicista. Louppe (2012), que enfatiza esse perfil tecnicista de concepção artística construída pelo ballet clássico, apresenta o ballet como algo muito distante do que viria a ser a concepção de dança da modernidade, que busca por uma expressão humana do ser. Louppe denuncia que entre o ballet e a dança moderna há uma distância genealógica, uma diametral oposição entre uma e outra que, em comum, teriam somente a visibilidade do potencial do corpo e do movimento como instrumento para um fazer artístico potente:

É dramaturgia do ser, a arte das artes. Contudo, essa dança não existe,(...) na cena decadente e tristemente sedutora do ballet, uma caricatura irrisória(...). É portanto, na dupla representação de uma ausência e de uma emergência, ao mesmo tempo impossível e esperada, que se elabora esse meio imaginário e sensível que não poderá sequer servir de berço, ainda menos de referência genealógica, à dança contemporânea. Trata-se antes da aurora de um pensamento não formado em que o corpo poderia reinventar a sua própria história (LOUPPE, 2012, p. 57).

O corpo do bailarino clássico busca transmitir leveza, domínio de si, altivez; no entanto, isto está distante da realidade física do bailarino que sofre com dores nos pés dentro das sapatilhas de ponta e com lesões musculares e tendinites. O bailarino usa de artifícios técnicos para equalizar essa disparidade, tornando algo que deveria ser uma expressão do ser, um desabafo, um momento de sensibilidade, num grito desesperado por visibilidade, em uma espécie de "dança das fadas" na qual as fadas calam suas dores e se expressam perfeitas e etéreas. Enquanto este grito poderia ser um grito, uma corrida no espaço, algo depressivo, limita-se à reprodução de uma 
Conceição | Conception

Revista do Programa de Pós-Graduação em Artes da

Cena, Universidade Estadual de Campinas

Performing Arts Graduate Program Journal, University of

Campinas

estética cunhada em um contexto que não mais corresponde às necessidades do "ser" contemporâneo.

O que é arte? Por que o ser humano faz arte? Se é por necessidade de se expressar, será que esta necessidade está sendo suprida ao apenas “executar passos corretamente"? Para onde vai o desejo e a necessidade?

Buscando uma alternativa para isso, a dança contemporânea contribuiu trazendo diversas alternativas estéticas; a dança moderna já trouxera diversos estados de corpo para a cena, a fim de proporcionar a expressão plena do ser não pela forma, mas por seu conteúdo. Louppe cita Nietzsche que, apesar de não ser bailarino, vê no corpo e na sua expressão por meio da dança o corpo como meio potencial para uma função humana de expressão artística:

Nietzsche, [...], previu uma arte sem representação, como a musica, que estaria mais próxima de uma vontade ou de um desejo puro sem imagem (LOUPPE, 2012, p. 55).

Neste processo de instalação da dança moderna, a busca por expressar-se significou o aumento na autonomia do pensamento crítico do bailarino a respeito de seu corpo. O resultado final não era mais o que importava; muitos trabalhos foram apresentados como processo, sem uma estética final perfeita, sem o acabamento de um produto, enfatizando a importância do experienciar, do vivenciar da prática corporal que agora buscava uma transformação, buscava uma conexão com o sujeito daquele corpo. A dança moderna não buscava mais se importar com "o que parece" ( LOUPPE, 2012, p. 51). Ao comparar o movimento da dança moderna com um aspecto antropológico, Louppe nos introduz a perspectiva também social da dança:

A fim de edificar o seu universo significante, um imaginário legível, o bailarino não dispõe de algo exterior ou suplementar à sua própria matéria. Ele nada modifica, nada apreende dos objetos do mundo, mesmo que se relacione com eles. (...) É pela recusa de qualquer tradição que pela primeira vez na história da humanidade a dança elabora um movimento que não é transmitido e que não reclama os valores exemplares de um grupo, voltando a sublinhar o aspecto não 
Conceição | Conception

Revista do Programa de Pós-Graduação em Artes da

Cena, Universidade Estadual de Campinas

Performing Arts Graduate Program Journal, University of

Campinas

somente artístico, mas antropológico, da revolução contemporânea do corpo (LOUPPE, 2012, p. 52).

\section{A dança e sua contribuição para o empoderamento}

Pensando nas consequências dessa busca de um movimento que venha de um corpo-sujeito, de um corpo pensante, encontramos também um corpo resultante desta busca; podemos visualizar este movimento gerando um corpo, antes subtraído de seus potenciais autorais, e agora munido de voz e fala. Neste processo é possível novamente visitar o termo empoderamento e identificar neste processo, que teve como ponto de partida e objetivo a dança, intervenções na esfera social, viabilizando a construção deste ser empoderado.

Distanciando-se um pouco da história da dança e da importância da dança moderna nesta questão, considerando o potencial histórico de empoderamento e transformações no ser social por meio do corpo, aproximamo-nos da educação, buscando, a partir do movimento, proporcionar a outras pessoas, no espaço de sala de aula, o processo que leve ao empoderamento. Encontramos diversos estudos sobre a aplicabilidade da dança como tal: "dança como ferramenta para enriquecimento das qualidades críticas, criativas e morais dos alunos" (SHAPIRO, 1998, p. 38).

Ainda há muito a ser conquistado pela sociedade no que diz respeito à autonomia, empoderamento, construção do senso crítico, opinião e conhecimento político. Portanto, há que se pensar em como contextualizar esta luta num momento em que classes oprimidas buscam por voz e representatividade, como os movimentos feminista, negro, LGBT, considerando o viés conservador do perfil familiar da sociedade brasileira. Shapiro apresenta este desafio e lança alguns princípios que podem ser tomados como eixos, motes para a elaboração deste processo, deste currículo para os fins do empoderamento: 
Conceição | Conception

Revista do Programa de Pós-Graduação em Artes da

Cena, Universidade Estadual de Campinas

Performing Arts Graduate Program Journal, University of

Campinas

Surge desse desafio epistemológico ocidental em nossas instituições
educacionais, uma visão que torna válidas as diferenças, nega
pretensões à verdade e busca dar poder às pessoas para a
transformação social (SHAPIRO, 1998, p. 36).

A autora, em seu trabalho, apresenta conteúdos didáticos, temáticas de aulas de dança para ministrar aulas a fim de provocar discussões que levem a uma reflexão crítica, que estimulem a criatividade, que considerem a experiência pessoal de cada um consolidando e construindo um núcleo reflexivo interno, no qual os alunos possam se basear para criar suas próprias ideias, elaborar suas próprias necessidades e estratégias para supri-las.

Existem diversos métodos que propiciam o empoderamento; propiciam, pois não é possível empoderar alguém. Este alguém empodera-se ativamente, conforme elucida Paulo Freire (2016); porém, assim como na história da construção da dança moderna foi detectada uma necessidade de expressão artística por um viés de certo modo antropológico, o empoderamento vem como consequência dessa busca pela alteridade. Acreditamos que este direcionamento despretensioso possa ser uma ferramenta para a aceitação do empoderamento de forma progressiva, porém, creio que esta intenção não deva ser arbitrária, inconsciente ou ocasional; é necessário que haja um embasamento em experiências e informações sérias a respeito deste tema para que este movimento seja construído de forma coerente e concisa, não de maneira indireta, superficial ou periférica.

Portanto, pode-se afirmar que alguns princípios para a elaboração de um currículo nesta área devam estar em intersecção, porém, os caminhos são amplos, e existem diversas maneiras deste empoderamento vir à tona em cada indivíduo. Cada experiência deve ser levada em consideração, tanto no aluno como também no professor. Há linhagens somáticas que têm enfoque artístico, como, por exemplo, a técnica Klauss Vianna ${ }^{8}$, que por meio do conhecimento anatômico desperta o ímpeto

8 A técnica Klauss Vianna é um método muito difundido no Brasil criado pela família brasileira dos 
Conceição | Conception

Revista do Programa de Pós-Graduação em Artes da

Cena, Universidade Estadual de Campinas

Performing Arts Graduate Program Journal, University of

Campinas

de respeito aos limites corporais do aluno, desencadeando um processo reflexivo. Há ainda métodos com maior enfoque na transformação e reflexão social, como a proposta por Shapiro, que tem seus conteúdos apresentados visando a uma reflexão, que embasa seus fundamentos numa pedagogia feminista; existem também as danças tradicionais populares que, por meio de uma movimentação da comunidade, estruturam-se em um processo de produção, gestão, criação e organização independente, que torna os integrantes autônomos e proativos, conscientes de seu potencial de mudança no mundo e na sociedade, à medida que se organizam de forma autônoma sem financiamentos e administração oficial centralizada. Nas manifestações populares tradicionais brasileiras, geralmente os ensaios e apresentações acontecem na rua, há que se criar esse espaço subjetivo para que as pessoas se concentrem, a energia flua e o ritual aconteça. As rodas de "brincadeiras" onde brincam os " brincantes" são potentes; fazem com que as pessoas abstraiam de sua rotina, seus afazeres e sigam para um espaço onde há cooperação, há olhares, há comunhão, movimentação expressiva, canto e música, algo que faz o brincante experienciar um mundo diferente daquele do dia-a-dia; fazem pensar em um mundo ideal, que toma forma, e criam potência para transformá-lo. Por um viés não conceitual, as manifestações populares trazem empoderamento.

Há que se ter consciência de que o empoderamento pode ocasionalmente aparecer mesmo inesperadamente. Há diversas formas de alcançar o objetivo em si, porém é necessário que estejamos conscientes do processo, de sua condução, de sua finalidade e de sua necessidade.

Sua necessidade é de uma educação que enfoque a práxis humana a luta consciente, ponderada para dar a nosso mundo uma nova forma, mais justa e compassiva (SHAPIRO, 1998).

busca o movimento através da expressividade. Há também um enfoque anatômico para uma movimentação não agressiva ao corpo. 
Conceição | Conception

Revista do Programa de Pós-Graduação em Artes da

Cena, Universidade Estadual de Campinas

Performing Arts Graduate Program Journal, University of

Campinas

\section{Que relação tem a dança com o empoderamento?}

Um argumento sustentado por educadores somáticos é que mente e corpo são integrados. Um exemplo é o de como o nosso corpo responde quando estamos felizes, ou estressados: nossos órgãos respondem, nossos músculos respondem. Há também as memórias do nosso corpo: lembranças que nosso corpo guarda de quando passamos por alguma situação marcante. Uma contratura muscular que o corpo lembra que fez quando subiu pela primeira vez numa árvore, ou quando caiu da bicicleta, ou quando ganhou uma festa surpresa.

É muito importante, aliás, essencial, que a educação, seja ela formal ou não, passe pelo estudo e descoberta do corpo, para que as pessoas percebam que são aquele corpo, e que esse corpo não serve só para meio de transporte do que elas são e, assim, um caminho de empoderamento seja construído, de modo que esses corpos-pessoas sejam protagonistas de suas histórias e militantes de suas causas.

Existem diversas formas de experienciar o corpo: brincadeiras, jogos, natação, futebol, atletismo, ginástica, artes marciais, teatro, circo... e dança. Essa experiência pode acontecer em lugares formais, não formais, seja de ensino de dança ou não.

Dança é uma forma de arte que é, também, uma atividade física. Esse pressuposto nos traz à antiga discussão sobre a dança ser ou não ser parte dos conteúdos de aulas de educação física. A despeito da Lei de Diretrizes e Bases, de 1996, fato é que muitas escolas de educação formal continuaram entendendo e promovendo o ensino de dança ou como parte da educação física, ou como atividade extracurricular, ao longo dos vinte e dois anos que transcorreram desde a promulgação da LDB.

É evidente que existem educadores físicos que podem ser, também, artistas, visto que a formação em dança ainda se realiza predominantemente no ensino não formal. A formação em dança no ensino não formal, no entanto - leia-se, aqui, especialmente as academias de dança - tem o intuito de formar bailarinos, 
Conceição | Conception

Revista do Programa de Pós-Graduação em Artes da

Cena, Universidade Estadual de Campinas

Performing Arts Graduate Program Journal, University of

Campinas

intérpretes, e não professores. Muitas das pessoas que aprendem dança nesse ambiente acabam por vir a ensinar dança nesse mesmo ambiente (academias), até mesmo como forma de complementação de renda, visto que são poucos os bailarinos no país que realmente sobrevivem das produções de dança. Vale ressaltar que o ambiente e os intuitos das academias, no entanto, são bem diferentes dos objetivos de uma escola de educação básica.

Quando falamos da importância do licenciado em dança ser o professor de dança em uma instituição formal de educação básica, não significa que numa aula de educação física a dança não possa ser abordada - inclusive seria interessante que aulas de educação física abordassem outros conhecimentos além dos quatro esportes coletivos que costumam ser estudados. Uma licenciatura em qualquer área de conhecimento pertinente à grande área Arte, no entanto, envolve conhecimentos específicos de arte-educação, educação em dança, em teatro, em música, especificidades estas que não são abordadas em nenhuma outra licenciatura que não as artísticas.

Um aspecto relevante é a mutualidade do lugar de ser arte-educador e ser artista: ser um para ser o outro, ser o outro para ser o um - nos parece que aqui está a especificidade mencionada anteriormente. Saber como é ser artista para saber tratar de arte em sala de aula (seja de educação formal, informal ou não formal).

No ambiente de educação básica formal, por lei, até 22 de setembro de 2016 uma pessoa não licenciada não poderia dar aula no ensino formal. Em 23 de setembro de 2016 o governo federal publicou em edição extraordinária do Diário Oficial a Medida Provisória no 746, de 22 de setembro de 20169 , promovendo alterações no ensino médio as quais incluem um resgate da ideia de "notório saber", na seguinte redação sobre profissionais aptos a ministrar aulas no ensino técnico: "profissionais com notório saber reconhecido pelos respectivos sistemas de ensino para ministrar conteúdos de áreas afins à sua formação para atender o disposto no

\footnotetext{
9 A lei $\mathrm{n}^{\mathrm{o}}$ 13.415, de 16 de fevereiro de 2017, que altera a LDB e reforma o Ensino Médio, tem origem na Medida Provisória n ${ }^{\circ}$ 746, de 22 de setembro de 2016.
} 
Conceição | Conception

Revista do Programa de Pós-Graduação em Artes da

Cena, Universidade Estadual de Campinas

Performing Arts Graduate Program Journal, University of

Campinas

inciso V do caput do art. 36" (Website do Planalto, 2016). Vejamos como ficou a redação atualizada do Artigo 610:

Art. 61. Consideram-se profissionais da educação escolar básica os que, nela estando em efetivo exercício e tendo sido formados em cursos reconhecidos, são: (Redação dada pela Lei no 12.014 , de 2009)

I - professores habilitados em nível médio ou superior para a docência na educação infantil e nos ensinos fundamental e médio; (Redação dada pela Lei $\mathrm{n}^{\circ} 12.014$, de 2009)

II - trabalhadores em educação portadores de diploma de pedagogia, com habilitação em administração, planejamento, supervisão, inspeção e orientação educacional, bem como com títulos de mestrado ou doutorado nas mesmas áreas; (Redação dada pela Lei $\mathrm{n}^{\circ} 12.014$, de 2009)

III - trabalhadores em educação, portadores de diploma de curso técnico ou superior em área pedagógica ou afim; e (Redação dada pela Medida Provisória $n^{\circ} 746$, de 2016)

IV - profissionais com notório saber reconhecido pelos respectivos sistemas de ensino para ministrar conteúdos de áreas afins à sua formação para atender o disposto no inciso $\mathrm{V}$ do caput do art. 36. (Incluído pela Medida Provisória $n^{\circ} 746$, de 2016) (Título VI da Lei 9394 de 20 de dezembro 1996, que estabelece a Lei de Diretrizes e Bases da Educação Nacional, grifos nossos).

Embora a Medida Provisória trate, neste caso, do ensino técnico, é fato que já se tem na educação básica um cenário no qual a disciplina Arte segue sendo ministrada apenas pelo professor de artes visuais (ou, em muitos casos, pelo próprio pedagogo), e o ensino de dança, quando existe, resume-se a uma extensão do modelo das academias de dança, contratando-se um professor de ballet para ministrar aulas nas dependências da escola ou, até mesmo, estabelecendo acordos comerciais com academias já existentes. A Medida Provisória n 746, portanto, abre brechas para tornar legal a situação irregular em que muitas escolas se encontram desde a publicação da LDB, em 1996.

10 O Art. $6^{\circ}$ da lei $n^{\circ} 13.415$, de 16 de fevereiro de 2017 altera o Art. 61 da LDB, que trata sobre o "notório saber", mantendo o texto do inciso IV da Medida Provisória $\mathrm{n}^{\circ} 746$, de 22 de setembro de 2016. 
Conceição | Conception

Revista do Programa de Pós-Graduação em Artes da

Cena, Universidade Estadual de Campinas

Performing Arts Graduate Program Journal, University of

Campinas

A categoria "O" da Secretaria da Educação do Estado de São Paulo permite, utilizando de brechas na LDB, que pessoas não licenciadas venham ministrando aulas desde antes da Medida Provisória. Essa categoria “O” foi instituída pela Lei Complementar 1093 de 16 de julho de 2009 do Estado de São Paulo, e ela dispõe sobre a contratação por tempo determinado (máximo de três anos ou o fim do período letivo correspondente) de profissionais da educação básica - no caso, professores. Ela alega necessidade temporária excepcional de contratação de profissionais por período determinado, firmado por contrato. A seleção desses profissionais acontece em processo seletivo simplificado e não exige licenciatura.

Antes da Medida Provisória $\mathrm{n}^{\mathrm{o}} 746$, não era permitido que profissionais sem licenciatura ou formação em Pedagogia ministrassem aulas em escola de educação básica num caráter de funcionário público, diferente da categoria " $\mathrm{O}$ " do Estado de São Paulo, que é uma contratação por período limitado e que também permite que profissionais de áreas diferentes da educação sejam professores dentro do contexto escolar formal.

Diante desse contexto, sabe-se que muitos professores de Arte não são formados nesta área, e pessoas que não têm formação na área em que ministram aulas podem não ter o domínio desse ensino. Acreditamos ser importante que o artista da dança que estuda ensino de dança ensine dança, porque a seleção de conteúdos e a forma de como trabalhá-los muito têm a ver com aquilo que quem ensina acredita ser importante para a formação de um cidadão empoderado.

\section{Para que(m) serve o teu conhecimento?}

Empoderamento é um termo originário do termo inglês empowerment e que ganhou significação especial no contexto educacional brasileiro quando Paulo Freire o conceituou como o processo de alguém que, por si, constrói seu fortalecimento, percurso esse que passa por aquisição de informações, reflexão sobre a própria condição, formulação das mudanças que serão construídas. Há aqui a 
Conceição | Conception

Revista do Programa de Pós-Graduação em Artes da

Cena, Universidade Estadual de Campinas

Performing Arts Graduate Program Journal, University of

Campinas

responsabilidade do professor nas proposições no sentido de estar ao lado do aluno em seu próprio processo de empoderamento. O professor, de certa forma, também se empodera no exercício docente: quais serão as propostas e como serão realizadas? Como fazer essa decisão: junto aos alunos, sozinho, com consciência do cronograma e das exigências curriculares? Quais os objetivos e estratégias?

Pensando no lado do aluno, pode-se dizer que tenha relação com as experiências de corpo, muitas vezes não valorizadas nas escolas de ensino básico, e que muito têm a contribuir com o desenvolvimento da pessoa: que pode passar a entender que ela é mais do que pensa ser, que aquele corpo com o qual se movimenta é ela, que o corpo reage às circunstâncias tanto quanto aos pensamentos (que não estão separados). Afinal, essas experiências de corpo possibilitam outras formas de contato com diferentes conhecimentos e outras formas de conviver com as pessoas.

Pela experiência de dança enquanto arte, pondera-se que o estímulo criativo coloca a pessoa num lugar de criar situações e soluções; coloca-a num lugar de protagonismo de suas próprias ações; fornece um ambiente favorável para que a pessoa crie de uma forma sensível. Nesse sentido, o artista da dança está melhor instrumentalizado para orientar aulas da arte da dança com qualidade.

Pensando no lado do professor de dança enquanto orientador e coordenador das atividades e experiências dentro de sala de aula, é importante a consciência de que o ensino de dança pode ser reflexo da produção de dança e vice-versa: o que se espera da dança vai para a sala de aula e reflete nas produções e formações na área. Pode-se pensar que isso é mais comum em academias de dança, mas também pode acontecer na escola formal de educação básica por causa do que se espera de aulas de dança, seja essa expectativa vinda da direção e coordenação da escola, dos pais de alunos, dos alunos ou do próprio professor. Dentro dessa correlação entre produção e ensino de dança, convém apresentar a importante pesquisa de Lucía Munevar, mestre em Performance/Dança pela Universidade Técnica de Lisboa. 
Conceição | Conception

Revista do Programa de Pós-Graduação em Artes da

Cena, Universidade Estadual de Campinas

Performing Arts Graduate Program Journal, University of

Campinas

A dissertação de Lucía Del Pilar Lancheros Munevar, intitulada “Dança Moderna e Feminismos", faz uma análise de uma parte da história da dança cênica ocidental sob a lente dos movimentos feministas - no plural porque, segundo a autora, "existem muitos feminismos, tão diferentes e críticos entre si que questionam a própria existência da categoria que os agrupa" (MUNEVAR, 2013, p. IV). O recorte que a autora escolhe para fazer tal análise é a partir da dança moderna - época de Isadora Duncan, Mary Wigman e Ruth St. Denis - até as danças contemporâneas. Desta forma, a autora estabeleceu relações entre a história da dança e as teorias de gênero:

[...] o feminismo além de ter origem no fato material de que a humanidade é dividida em homens e mulheres e que esta divisão não só provém da aparência dos genitais dos indivíduos, no momento de seu nascimento, como também produz um trato diferenciado; para além deste fato não existe qualquer consenso sobre o que significa o termo gênero, qual é a sua causa, quais as suas consequências, se é necessário, inevitável, fixo ou, pelo contrário, circunstancial e temporal (MUNEVAR, 2013, p. VI).

Munevar divide esse grande recorte de tempo da dança em blocos menores e seleciona artistas cujas obras serão analisadas. O primeiro bloco é formado por Isadora Duncan, Ruth St. Denis e Mary Wigman, estas que buscam em suas obras uma representação de uma mulher universal, ainda que cada uma a sua forma. Esta criação de um ideal de algo - no caso, do que é a mulher - relaciona-se com o pensamento iluminista: "O Iluminismo aprofunda a dicotomia entre o corpo e a mente com clara vitória desta última e, com este triunfo, acredita na possibilidade de abstracções com validade universal" (MUNEVAR, 2013, p. 8). Nessa época, no campo das lutas das mulheres, o que acontecia era a luta pelo sufrágio feminino. $\mathrm{O}$ argumento para essa luta é que, assim como os homens, mulheres são seres com "capacidade de pensamento" (sic) e que podem escolher seus representantes. As mulheres que levaram à frente essa luta pensavam o que era ser mulher sem distinções entre os recortes de classe social, cor ou qualquer outro, generalizando o que é ser mulher a partir de suas próprias experiências. 
Conceição | Conception

Revista do Programa de Pós-Graduação em Artes da

Cena, Universidade Estadual de Campinas

Performing Arts Graduate Program Journal, University of

Campinas

No segundo capítulo, o assunto é uma divisão radical entre homem e mulher, e essa ruptura é abordada dentro das obras dos coreógrafos Martha Graham e Ted Shawn. "[...] todos os seres humanos devem ter os mesmos direitos e oportunidades ou, pelo contrário, as mulheres são irreversivelmente diferentes ao homem"? (MUNEVAR, 2013, p. 15), e é dentro dessa última questão que se constroem as obras daqueles artistas. Martha Graham, por exemplo, não demonstrava os movimentos que seus bailarinos homens deveriam fazer com o argumento de que ela, sendo mulher, não poderia realizar esses movimentos. Ted Shawn não coloca movimentos ditos femininos em sua companhia que só tem homens. Nessa época, no movimento sufragista das francesas, a ideia de mulher sustentada era generalista e baseada na maternidade: a mulher que cuida, que é sentimental, a mulher que é um anjo. Martha Graham, ao representar seus próprios dramas na cena e colocando-os como as necessidades femininas, dicotomiza o homem e a mulher. Ted Shawn, que teve uma companhia de dança só de homens na época da Primeira Guerra Mundial, em que a relação entre nacionalismo e virilidade estava muito forte, gerou motivo de afirmação dos homens daquela companhia. Este possivelmente foi um dos motivos pelo qual Ted Shawn só incorporou movimentos fortes, enérgicos, "masculinos" em suas obras: para a afirmação dela própria.

No terceiro capítulo, a preocupação dos artistas estudados (Alwin Nikolais, Merce Cunningham, Ivonne Rainer, Schlemmer) era criar obras que atingissem a universalidade; que a abstração da coreografia pudesse gerar uma obra de arte que seria reconhecida como tal em qualquer tempo ou lugar. Dessa forma, buscou-se a não diferenciação dos corpos em cena e a não utilização de drama. A dança é o movimento por si só e há a preocupação com essa pureza:

Chegados a este ponto, convém questionar se a omissão deliberada do gênero, enquanto característica do indivíduo nas peças dos coreógrafos estudados, é, per se, um fato que incorpora o reconhecimento da igualdade entre homem e a mulher e o desprendimento dos estereótipos de gênero ou se, pelo contrário, 
Conceição | Conception

Revista do Programa de Pós-Graduação em Artes da

Cena, Universidade Estadual de Campinas

Performing Arts Graduate Program Journal, University of

Campinas

reforça estereótipos e realidades dominantes ou é, simplesmente, um fato supérfluo sem grande relevância? (MUNEVAR, 2013, p. 41).

Tratando do movimento feminista daquele tempo, sua preocupação era em afastar-se da ideia já construída do que era ser mulher. Uma das maneiras encontradas foi tentar se aproximar da ideia do que era ser masculino e, de certa forma, desprezar o que era chamado de feminino, que era considerado algo secundário e inferior. Dentro da dança daqueles coreógrafos mencionados, os figurinos eram iguais para todos os bailarinos, mas em geral as roupas utilizadas eram "masculinas", como se fosse uma uniformização dos corpos. As movimentações, desligadas das emoções, eram planejadas de forma bastante racional, utilizando de estratégias geométricas. Dançar assim, para Ivonne Rainer, era uma forma de ela se afirmar enquanto coreógrafa, mostrando que mulheres também podem criar dessa forma abstrata. Alwin Nikolais, por exemplo, acreditava que a abstração era uma capacidade masculina e, portanto, homens eram melhores artistas que as mulheres.

No quarto capítulo é abordado o gênero enquanto construção: era tempo da publicação de O Segundo Sexo, de Simone de Beauvoir e de Foucault e sua teoria de gênero enquanto dispositivo para regular as ações dos indivíduos. Posteriormente, temos Judith Butler com sua proposta de gênero enquanto atuação/performance, que se constrói ao longo da vida.

O gênero é a estilização repetida do corpo, uma sucessão de ações repetidas dentro dum marco regulador muito estrito que se imobiliza com o tempo para criar a aparência de substância, duma espécie natural do ser (MUNEVAR, apud BUTLER, 2007, p. 98).

Essa visão de gênero, colocada em cena, é então uma postura política; é encarar a cena como espaço de luta política. Essa preocupação está presente nas obras de Bill T. Jones, Jacky Lansley, X6 Collective. “Assim, a forma de representação dos gêneros, das relações entre eles e a crítica ao sistema atual, será um dos pontos 
Conceição | Conception

Revista do Programa de Pós-Graduação em Artes da

Cena, Universidade Estadual de Campinas

Performing Arts Graduate Program Journal, University of

Campinas

centrais no trabalho desses artistas" (MUNEVAR, 2013, p. 55). Passa-se a ter interesse pelas subjetividades dos intérpretes em cena, e não a preocupação de uniformização, uma vez que esta nega a realidade, e "ficar na mera omissão das diferenças significa não fazer nada para que os aspectos negativos dessa materialidade mudem" (MUNEVAR, 2013, p. 56).

Em seguida, Munevar trata que, dependendo de como o ato travesti em cena seja feito, ele pode atuar como um reforçador de estereótipos em vez de um ato que ultrapassa os limites entre os sexos, que coloca em cena a questão da performance de gênero:

Logo, na medida em que todo comportamento de género é uma performance deixa de fazer sentido, especialmente para as práticas transexuais, falar de género real e/ou falso, de género natural e/ou artificial. Assim, no caso do transexual, tanto a atuação de género conforme a sua psicologia e desconforme com o género que lhe fora assinalado ao nascer como a atuação segundo este último (que e que a sociedade reclama como verdadeira), são igualmente falsas porque, se falso é tudo aquilo que seja produto de performance - no sentido teatral do termo -, então todo o género, concordante ou não com as características genitais, é falso, é fictício (MUNEVAR, 2013, p. 50).

Aqui aparece a questão de performance de gênero. A Organização Mundial da Saúde (OMS) considera "doenças associadas às condutas sexuais" e "desordens de identidade sexual" as identidades que divergem a anatomia genital das condutas de gênero socialmente aceitas. Espetáculos travestis que questionam os estereótipos de gênero vão de encontro a esse pensamento higienista, principalmente se vão além da imitação do que é um homem ou uma mulher e propõem novas possibilidades de identidades. Essas questões que misturam arte e sociedade/realidade podem ser trabalhadas em sala de aula de forma a rever os pensamentos e comportamentos dos alunos, professor e que afetam toda a comunidade escolar, como questões de opressão. Coloca em cheque as noções de gênero consideradas reais ou artificiais.

No capítulo quinto, Munevar trata do pós-colonialismo: 
Conceição | Conception

Revista do Programa de Pós-Graduação em Artes da

Cena, Universidade Estadual de Campinas

Performing Arts Graduate Program Journal, University of

Campinas

\begin{abstract}
Baseado nas premissas de colocar sob suspeita as pretensões de neutralidade do pensamento produzido no ocidente, convencidos que existem vozes na história que têm sido sistematicamente condenadas ao silêncio e que as noções universais resultam na imposição do modelo e forma de perceber o mundo de quem tem a posição dominante, o pensamento pós-colonial faz uma revisão crítica da forma como se produz o conhecimento e tenta oferecer um espaço para que as vozes locais (especialmente as não ocidentais, mas também todos os grupos que não se localizam na situação de poder), usualmente mudas, falem e produzam a sua versão da história (MUNEVAR, 2013, p. 63).
\end{abstract}

Dentro dos movimentos feministas, as tentativas de criar uma identificação universalista do que é ser mulher acabaram marginalizando vários grupos de mulheres que não se encaixaram dentro daqueles padrões: um exemplo dado no texto é o feminismo universalista dos anos 1950 nos EUA, que via na família um lugar onde há opressão, enquanto mulheres negras da mesma época tinham na família um lugar de refúgio à opressão racial que sofriam - cuidado com as individualidades que deve ser tomado ao promover essas discussões.

É possível perceber, ao longo da história da dança apresentada por Munevar, que mulheres da dança criaram suas estratégias para se afirmarem e serem reconhecidas nesse meio que também carrega em si muitos machismos: difícil lembrar de nomes reconhecidos de coreógrafas na história da dança cênica ocidental antes de Isadora Duncan, Ruth St. Denis e Mary Wigman. Ivonne Rainer escolheu mostrar que era capaz de criar assim como homens faziam em sua época, e que ainda afirmavam que existiam capacidades de abstração que só homens tinham. Essas mulheres, ao se empoderarem e afirmarem seus lugares, geraram representatividade nessa área, e dessa forma mostram para o mundo que mulher pode ser muito mais do que só bela intérprete de uma dança criada por homens, e que este não é o "devido lugar" de uma mulher estar na dança. Elas criaram espaço e abriram caminhos para que outras mulheres adentrassem essa área. Outras representatividades também são apresentadas na dissertação de Munevar: Bill T. Jones, ao colocar questões negras, de gênero, de afetividade, de homossexualidade 
Conceição | Conception

Revista do Programa de Pós-Graduação em Artes da

Cena, Universidade Estadual de Campinas

Performing Arts Graduate Program Journal, University of

Campinas

em cena, sendo que ele próprio tinha essas questões, mostra que é possível um homem negro e homossexual ter lugar de prestígio e reconhecimento na dança, em equidade a outros criadores e intérpretes.

Um professor de dança, no seu ato de ensinar, deve perceber questões que são relevantes para o processo de empoderamento de seus alunos e trabalhá-las no ambiente de ensino. Questões de performance de gênero, LGBT, raciais, dentre outras ligadas às opressões, são sempre relevantes e presentes em todo meio. Identificar como isto está presente nas produções de dança, trazer esse conteúdo para a sala de aula e fazer conexões com as realidades dos alunos pode ser um caminho para um professor de dança. Questionar que tipos de movimentações são "masculinas ou femininas", se isso é relevante ou não, ou se deve haver essa distinção é uma forma de questionar performance de gênero.

Questionar a presença e ausência de pessoas com deficiências físicas e outras minorias na dança é uma forma de construir conhecimento sobre a manutenção de poderes, de representatividade. Levantar assuntos, corporal e verbalmente, que coloquem os alunos e professor em situações que devem ser resolvidas, envolvendo questões de gênero, de raça, de inclusão é fundamental. A forma como o professor trata cada um de seus alunos, coletiva e individualmente, também reflete a forma como ele pensa e acredita essas várias questões, e por isso é importante pensar as estratégias de abordagens, as tendências pedagógicas nas quais o educador se orienta para o ensino e as individualidades dos alunos ao se relacionarem com estes. O professor, ao pensar e trabalhar essas questões, também pode se colocar no processo de empoderamento, uma vez que constrói conhecimento, reconhece sua condição e formula suas ações, tudo dentro e fora da sala de aula.

É o licenciado em dança - também artista da dança - que pode estar preparado para levantar todas essas questões, uma vez que ele se prepara para tratar dança como arte, relacionando esses assuntos com o ensino dessa área. $\mathrm{O}$ empoderamento é desejado e necessário para o ensino de dança atual (e em qualquer momento histórico). É percebido que todas essas inquietações já estão inseridas nas 
Conceição | Conception

Revista do Programa de Pós-Graduação em Artes da

Cena, Universidade Estadual de Campinas

Performing Arts Graduate Program Journal, University of

Campinas

produções artísticas e podem dialogar com o ensino de arte. Diante do cenário político com projetos de Escola Sem Partido, BNCC que não trata dança como área de conhecimento, Medida Provisória n 746 e o "notório saber", Lei Complementar $\mathrm{n}^{\mathrm{o}} 1093$ e a categoria " $\mathrm{O}$ ", dentre outros, ensinar dança enquanto arte que carrega um discurso, uma visão de mundo, e tratar essas questões torna-se um ato de luta e de resistência.

\section{REFERÊNCIAS}

ALVARENGA, A. L. Klauss Vianna e o Ensino da Dança: uma experiência educativa em movimento. 2009. 306 f. Tese (Doutorado em Educação e Inclusão Social) - Instituto de Educação, Universidade Federal de Minas Gerais, Belo Horizonte. 2001.

BANES, S. Greenwich Village 1963: avant-garde, performance e o corpo efervescente. Tradução: Mauro Gama. Rio de Janeiro: Rocco, 1999.

BEAUVOIR, S. O Segundo Sexo. 1. Fatos e Mitos. Tradução de: Sérgio Milliet. São Paulo: Círculo do Livro S.A., 1949.

BRASIL. Medida Provisória ${ }^{0}$ 746, de 22 de setembro de 2016. Institui a Política de Fomento à Implementação de Escolas de Ensino Médio em Tempo Integral, altera a Lei $\mathrm{n}^{0}$ 9.394, de 20 de dezembro de 1996, que estabelece as diretrizes e bases da educação nacional, e a Lei no 11.494 de 20 de junho 2007, que regulamenta o Fundo de Manutenção e Desenvolvimento da Educação Básica e de Valorização dos Profissionais da Educação, e dá outras providências. Disponível em: http:/ / www.planalto.gov.br/ccivil_03/_Ato2015-2018/2016/Mpv/mpv746.htm. Acesso em 30 out. 2016.

BRASIL. Ministério de Educação e Cultura. Lei n ${ }^{0}$ 9394/96, de 20 de dezembro de 1996. Estabelece as diretrizes e bases da Educação Nacional. Brasília. Disponível em: https:// www.planalto.gov.br/ccivil_03/Leis/L9394.htm. Acesso em 30 out. 2016.

COURTINE J. J.; VIGARELLO G.; CORBIN A. História do Corpo: As mutações do olhar: O século XX. Petrópolis, RJ: Vozes, 2009. 
Conceição | Conception

Revista do Programa de Pós-Graduação em Artes da

Cena, Universidade Estadual de Campinas

Performing Arts Graduate Program Journal, University of

Campinas

FORTIN, S. Transformação de práticas de dança. Lições de Dança 4, Rio de Janeiro: UniverCidade Editora, 2004.

FORTIN, S. "Transformação de práticas de dança". Lições de dança. Rio de Janeiro: UniverCidade Editora, 2003.

FOUCAULT, M. “Vigiar e punir: historia da violência nas prisões”. Vozes, 1987.

FREIRE, P. Pedagogia do oprimido. 17 ed. Rio de Janeiro: Paz e Terra, 1987.

GREEN, J. Emancipatory pedagogy?: Women's Bodies and The Creative Process in Dance. Frontiers: A Journal of Women Studies,Ohio, v. 21, n. 3, pp.124-140. 2000.

KUHN, T. A Estrutura das Revoluções Científicas. Trad. Beatriz Vianna Boeira e Nelson Boeira. 12.ed. São Paulo: Perspectiva, 2013.LOUPPE, L. Poética de dança contemporânea. Orfeu Negro, 2012.

LOUPPE, L. Corpos Híbridos. In: ANTUNES, Arnaldo et al. Lições de Dança, 2. Rio de Janeiro: UniverCidade, 2000. pp. 27-40.

MUNEVAR, Lucia Lancheros. Dança moderna e feminismos. 2013. Dissertação de Mestrado em Performance Artística / Dança. Faculdade de Motricidade Humana, Universidade Técnica de Lisboa. Lisboa, 2013. Disponível em: http:/ / hdl.handle.net/10400.5/5492

MUNIZ, Z. Rupturas e Procedimentos da Dança Pós-Moderna. Revista O Teatro Transcende, Blumenau, v. 16, n. 2, p. 63-80, 2011.

NOGUEIRA, I. C. Do nascimento das políticas de rede à poética de multidão. Salvador, IV Reunião Científica de Pesquisa e Pós-Graduação em Artes Cênicas. Disponível em: http://portalabrace.org/ivreuniao/GTs/DancaTecnologia/Nogueira.pdf Acesso em: 07 nov. 2016. 
Conceição | Conception

Revista do Programa de Pós-Graduação em Artes da

Cena, Universidade Estadual de Campinas

Performing Arts Graduate Program Journal, University of

Campinas

RODRIGUES, G. Bailarino-pesquisador-intérprete: processo de formação. Rio de Janeiro: Funarte, 1997.

SÃO PAULO (Estado). Lei Complementar $n^{0} 1.093$ de 16 de julho de 2009 (Atualizada até a Lei Complementar $n^{0}$ 1.277, de 22 de dezembro de 2015). Dispõe sobre a contratação por tempo determinado de que trata o inciso X do artigo 115 da Constituição Estadual e dá outras providências correlatas. Disponível em: http://www.al.sp.gov.br/repositorio/legislacao/lei.complementar/2009/alteracaolei.complementar-1093-16.07.2009.html. Acesso em: 20 out. 2016

SENADO FEDERAL - Website. Dispõe sobre o ofício do profissional da dança.

Disponível em:

http:/ / www.camara.gov.br/proposicoesWeb/prop_mostrarintegra?codteor $=144411$

3 Acesso em 15 de out. 2016

SHAPIRO, S. Em direção a professores transformadores: perspectivas feminina e critica no ensino da dança. Pro-posições, Campinas, Vol. 9 N 2 [26] Junho de 1998. She's Beautiful When She's Angry. Direção: Mary Dore. Produção: Mary Dore, Nancy Kennedy. Documentário histórico, 92 min, 2014.

VALOURA, L. de C. Paulo Freire, o educador brasileiro autor do termo Empoderamento, em seu sentido transformador. 2005/2006. Disponível em: <http:/ / tupi.fisica.ufmg.br/michel/docs/Artigos_e_textos/Comportamento_organi zacional/empowerment_por_paulo_freire.pdf>. Acesso em: 05 set. 2016.

VALOURA, L. de C. Paulo Freire, o educador brasileiro autor do termo Empoderamento, em seu sentido transformador. 2005/2006. Disponível em: <http://tupi.fisica.ufmg.br/michel/docs/Artigos_e_textos/Comportamento_organi zacional/empowerment_por_paulo_freire.pdf>. Acesso em: 05 set. 2016.

VIANNA, K. A Dança. São Paulo: Summus Editorial, 2005.

WEBSITE DA CÂMARA DOS DEPUTADOS. Constituição de 1988. Disponível em: http:/ / www2.camara.leg.br/legin/fed/consti/1988/constituicao-1988-5-outubro1988-322142-publicacaooriginal-1-pl.html Acesso em 30/10/2018.

WEBSITE DO PROGRAMA ESCOLA SEM PARTIDO. Por uma lei contra o abuso da liberdade de ensinar. Disponível em: http:/ / www.programaescolasempartido.org/saiba-mais/ Acesso em: 10 out. 2016. 